\title{
A Photoswitchable Inhibitor of the Calcium Channel TRPV6
}

Micael R. Cunha, ${ }^{\dagger}$ Rajesh Bhardwaj, ${ }^{ \pm}$Sonja Lindinger, ${ }^{\ddagger}$ Carmen Butorac, ${ }^{\ddagger}$ Christoph Romanin, $* ¥$ Matthias A. Hediger, ${ }^{* \pm}$ Jean-Louis Reymond ${ }^{* \dagger}$

${ }^{\dagger}$ Department of Chemistry and Biochemistry, NCCR TransCure, University of Bern, Freiestrasse 3, 3012 Bern.

${ }^{ \pm}$Institute of Biochemistry and Molecular Medicine, NCCR TransCure, University of Bern, Bühlstrasse 28, 3012 Bern, Switzerland \& Department of Nephrology and Hypertension, University Hospital Bern, Inselspital, 3010 Bern, Switzerland

${ }^{¥}$ Institute of Biophysics, Johannes Kepler University Linz, Gruberstrasse 40, 4020 Linz.

\section{$†$ SUPPORTING INFORMATION}

Table of contents

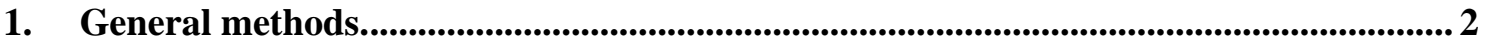

2. Synthetic chemistry, procedure and physical properties..................................................... 3

3. Copy of ${ }^{1} \mathrm{H}$ and ${ }^{13} \mathrm{C}$ NMR spectra ..................................................................................... 11

4. X-Ray crystal structure report............................................................................................................ 31

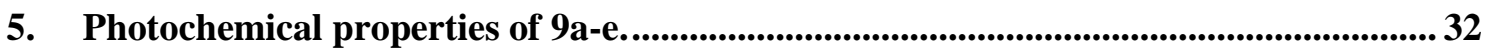

6. Analytical RP-UPLC purity for compounds 9a-e ........................................................... 34

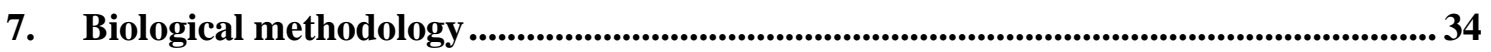

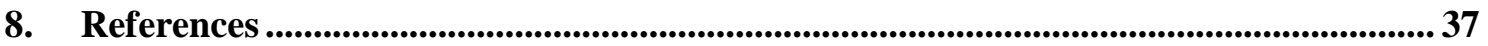



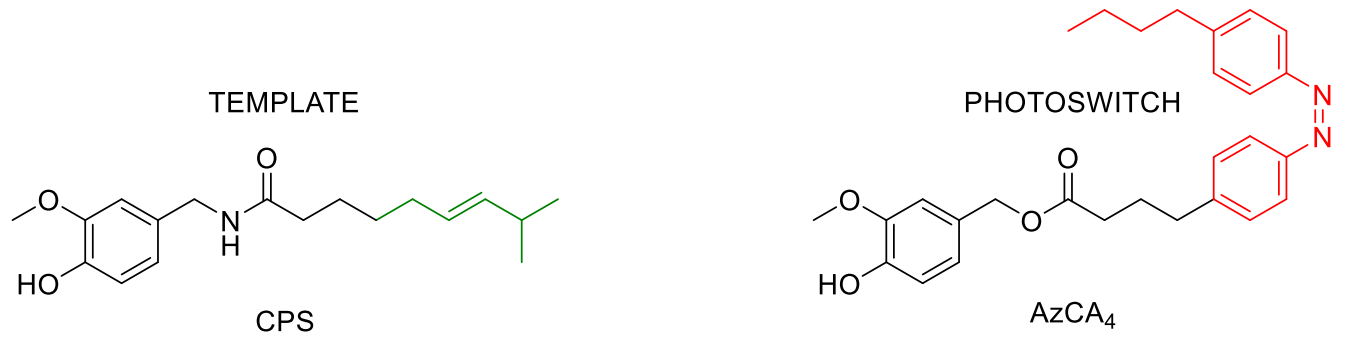<smiles>[R]C(C)CCNC(=S)N1CCc2cc(O)c(O)cc2C1</smiles><smiles>Oc1cc2c(cc1O)CN(C(=S)NCCc1ccc(N=Nc3ccc(C(F)(F)F)cc3)cc1)CCC2</smiles><smiles>CC(C)(C)c1ccc(NC(=O)N2CCN(c3ncccc3Cl)CC2)cc1</smiles><smiles>O=C(Nc1ccc(/N=N/c2ccccc2)cc1)N1CCN(c2ncccc2Cl)CC1</smiles>

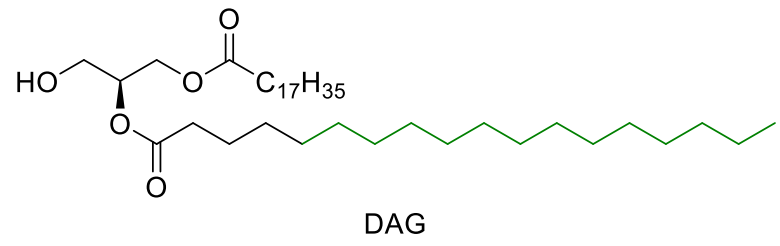

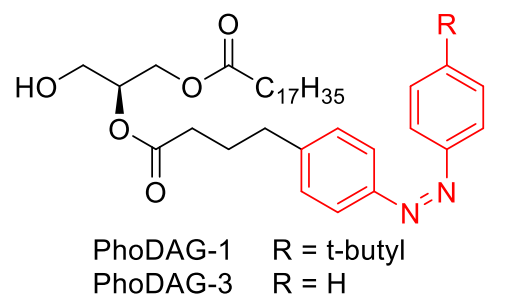

Figure S1. On the left side, structures of the bioactive compounds used as templates to generate photoswitches. On the right side, the phenyldiazo group is depicted in the active form $(Z)$. CPS = capsaicin, TRPV activator; $\mathrm{CPZ}=$ capsazepine, TRPV1 inhibitor; $\mathrm{BCTC}$ = N-(4-Tert-butylphenyl)-4-(3-chloropyridin-2-yl)piperazine-1-carboxamide; TRPV1 inhibitor; $\mathrm{DAG}=$ diacylglycerol; TRPC2/3/6 activator.

\section{General methods.}

All commercial reagents were used without further purification. Dry solvents were obtained directly from a drying solvent system. Chromatographic purifications were performed using silica gel (Sigma-Aldrich, 230-400 mesh). Automated chromatographic purification was performed with Puriflash 430 system (Interchim) using Teledyne Isco normal phase RediSepRf cartridge and detection by UV absorption (214 nm). Low resolution mass spectra were obtained by electron spray ionization (ESI), positive mode (Thermo Scientific LCQ Fleet). High resolution mass spectra were obtained by ESI, positive mode (Thermo Scientific LTQ OritrapXL). ${ }^{1} \mathrm{H}$ and ${ }^{13} \mathrm{C}-\mathrm{NMR}$ spectra were 
recorded at $300 \mathrm{MHz}$ and $75 \mathrm{MHz}$, respectively (Bruker $\mathrm{AV} 300$ ). ${ }^{1} \mathrm{H}$ and ${ }^{13} \mathrm{C}$ chemical shifts are quoted relative to solvent signals. MestreNova was used for further analysis of the spectra. The purity of all tested compounds was $>95 \%$ (Table S13), as confirmed by analytical RP-UHPLC with detection at $214 \mathrm{~nm}$, on a Dionex Ultimate 3000 RSLC System (DAD-3000 RS Photodiode Array Detector) and Dionex Acclaim RSLC 120 column $(\mathrm{C} 18,3.0 \times 50 \mathrm{~mm}$, particle size $2.2 \mu \mathrm{m}, 120 \AA$ pore size $)$ at a flow rate of 1.2 $\mathrm{mL} / \mathrm{min}$. Data recording and processing was done with Dionex Chromelon Management System (v. 6.8), and Xcalibur (v. 2.2, Thermo Scientific). Eluents for analytical RPUHPLC were as follow: A: miliQ-deionized water with 0.05\% TFA and D: HPLC-grade acetonitrile/miliQ-deionized water (9/1) with $0.05 \%$ TFA. Conditions for analytical RPUHPLC were as follow: in 4.5 min from $100 \%$ A to $100 \% \mathrm{D}$, then staying on $100 \% \mathrm{D}$, or in 7.5 min from $100 \%$ A to $100 \% \mathrm{D}$, then staying on $100 \% \mathrm{D}$. Chemical names were generated using ChemDraw Professional 17.0 (PerkinElmer Informatics).

\section{Synthetic chemistry, procedure and physical properties.}

(E)-1-(6-(phenyldiazenyl)pyridin-3-yl)piperazine, double hydrochloride salt (5a). To a warm solution $\left(60^{\circ} \mathrm{C}\right)$ of $\mathrm{NaOH}(60.0 \mathrm{mmol}, 2.40 \mathrm{~g})$ in a $\mathrm{H}_{2} \mathrm{O}(4.7 \mathrm{~mL})$, was added a solution of 3a $(5.00 \mathrm{mmol}, 1.39 \mathrm{~g})$ in benzene $(0.564 \mathrm{~mL})$. After become soluble, nitrosobenzene $(5.00 \mathrm{mmol}, 535.5 \mathrm{mg})$ was added in small portions. After addition, the reaction was refluxed $\left(100^{\circ} \mathrm{C}\right)$ for $10 \mathrm{~min}$. Once reached r.t., the mixture was diluted with benzene $(10.0 \mathrm{~mL})$ and extracted with $\mathrm{H}_{2} \mathrm{O}(2 \times 10 \mathrm{~mL})$. The collected aqueous phase was washed with $10.0 \mathrm{~mL}$ of benzene. The organic phases were collected, dried over $\mathrm{MgSO}_{4}$, and concentrated over vacuum. Column chromatography (Hexanes 5:5 AcOEt) afforded the $4 \mathbf{a}$ as an orange solid (835.5 $\mathrm{mg}, 2.27 \mathrm{mmol}, 45 \%)$. The previously obtained compound was suspended an aqueous solution of $\mathrm{HCl}(1 \mathrm{M}, 100.0 \mathrm{~mL})$ was refluxed $(100$ ${ }^{\circ} \mathrm{C}$ ) o.n. After completion, the solvent was partially removed by vacuum (until $10.0 \mathrm{~mL}$ ) to give 5a as an orange powder (647.6 mg, $2.13 \mathrm{mmol}, 84 \%) .{ }^{1} \mathrm{H}-\mathrm{NMR}\left(300 \mathrm{MHz}, \mathrm{D}_{2} \mathrm{O}\right.$, $\delta=\mathrm{ppm}): \delta 7.80(\mathrm{~s}, 1 \mathrm{H}), 7.53-7.36(\mathrm{~m}, 7 \mathrm{H}), 3.63(\mathrm{~s}, 4 \mathrm{H}), 3.46(\mathrm{~s}, 4 \mathrm{H}) .{ }^{13} \mathrm{C}-\mathrm{NMR}(75$ $\left.\mathrm{MHz}, \mathrm{D}_{2} \mathrm{O}, \delta=\mathrm{ppm}\right): \delta 150.5,147.4,144.9,133.7,129.6,128.4,126.5,123.5,119.5$, 117.5, 43.1, 42.5, 40.3. HRMS m/z calculated for $\mathrm{C}_{15} \mathrm{H}_{18} \mathrm{~N}_{5}: 268.1557\left([\mathrm{M}+\mathrm{H}]^{+}\right)$; found: 268.1563 .

(E)-1-(4-(phenyldiazenyl)phenyl)piperazine, hydrochloride salt (5b). To a solution of $\mathbf{3 b}(5.00 \mathrm{mmol}, 1.54 \mathrm{~g})$ in AcOEt $(50.0 \mathrm{~mL})$ under Argon, was added $\mathrm{Pd} / \mathrm{C} 10$ $\%$. The suspension was stirred vigorously under an atmosphere of $\mathrm{H}_{2}$ (balloon) for $48 \mathrm{~h}$ 
at r.t. The mixture was filtered through Celite, which was washed several times with AcOEt. The filtrate was concentrated in vacuum to give the crude amine derivative as a pale pink solid. The crude amine was solubilized in $\mathrm{AcOH}(10.0 \mathrm{~mL})$ and was added to a solution of nitrosobenzene $(5.00 \mathrm{mmol}, 536 \mathrm{mg}$; $\mathrm{AcOH}, 10 \mathrm{~mL})$. The reaction mixture was stirred at r.t. for $24 \mathrm{~h}$ until completion (monitored by TLC). The solvent was removed by vacuum, and the crude was purified by column chromatography (hexanes 7:3 AcOEt) to afford $\mathbf{4 b}$ as an orange solid (1.12 g, $3.07 \mathrm{mmol}, 61 \%$ over 2 steps). A suspension of the previous obtained compound (3.07 mmol, $1.12 \mathrm{~g}$ ) in an aqueous solution of $\mathrm{HCl}(1$ M, $250.0 \mathrm{~mL})$ was refluxed $\left(100^{\circ} \mathrm{C}\right)$ o.n. After completion, the solvent was partially removed by vacuum (until $10.0 \mathrm{~mL}$ ). Compound $\mathbf{5 b}$ was obtained as a dark-purple solid (hydrochloride salt) after lyophilization ( $929.0 \mathrm{mg}, 3.07 \mathrm{mmol}, 61 \%$ over 3 steps). ${ }^{1} \mathrm{H}$ NMR (300 MHz, $\left.\mathrm{CD}_{3} \mathrm{OD}, \delta=\mathrm{ppm}\right): \delta 7.91(\mathrm{dt}, \mathrm{J}=3.1,2.1 \mathrm{~Hz}, 2 \mathrm{H}), 7.86(\mathrm{dt}, \mathrm{J}=2.1,1.6$ $\mathrm{HZ}, 2 \mathrm{H}), 7.50(\mathrm{~m}, 3 \mathrm{H}), 7.18(\mathrm{dt}, \mathrm{J}=3.1,2.1 \mathrm{~Hz}, 2 \mathrm{H}), 3.62(\mathrm{t}, \mathrm{J}=5.5,5.0 \mathrm{~Hz}, 4 \mathrm{H}), 3.41$ $(\mathrm{t}, \mathrm{J}=5.5,5.0 \mathrm{~Hz}, 4 \mathrm{H}) .{ }^{13} \mathrm{C}-\mathrm{NMR}\left(75 \mathrm{MHz}, \mathrm{CD}_{3} \mathrm{OD}, \delta=\mathrm{ppm}\right): \delta 142.1,131.5,130.2$, 125.6, 123.4, 116.9, 46.7, 44.6. HRMS m/z calculated for $\mathrm{C}_{16} \mathrm{H}_{19} \mathrm{~N}_{4}: 267.1604\left([\mathrm{M}+\mathrm{H}]^{+}\right)$; found: 267.1603 .

(E)-(4-piperazin-1-ylphenyl)-(3-pyridyl)diazene, double hydrochloride salt (5c). A solution of 3c $(8.09 \mathrm{mmol}, 761.0 \mathrm{mg})$ in a mixture $(1: 1)$ of $\mathrm{HCl} / \mathrm{H}_{2} \mathrm{O}(55.0 \mathrm{~mL})$, was stirred in an ice bath. Then, a solution of $\mathrm{NaNO}_{2}\left(7.35 \mathrm{mmol}, 507.0 \mathrm{mg}\right.$, in $\left.\mathrm{H}_{2} \mathrm{O}, 5.0 \mathrm{~mL}\right)$ was added drop-by-drop to the previous suspension, and the mixture was stirred at $0{ }^{\circ} \mathrm{C}$, to generate in situ 4c. After 30 min, phenylpiperazine (7) was added, drop-by-drop, and the mixture was allowed to stir o.n. at r.t. The reaction was quenched by addition of a saturated solution of $\mathrm{NaHCO}_{3}$ until pH aprox. 8.0. The solids were filtered off, washed with $\mathrm{H}_{2} \mathrm{O}(10.0 \mathrm{~mL})$, and solubilized in an aqueous solution of $\mathrm{HCl}(5.0 \%)$. The solved was removed by vacuum. The crude was solubilized in dry $\mathrm{MeOH}$ and the compound was precipitated by addition of dry diethyl ether. The solids were collected, washed with hexanes, dried in vacuum. The title compound was solubilized in $\mathrm{H}_{2} \mathrm{O}$ and lyophilized to give $5 \mathrm{c}$ as a purple powder (1.63 g, $4.79 \mathrm{mmol}, 65 \%$ over 2 steps). ${ }^{1} \mathrm{H}-\mathrm{NMR}$ (300 MHz, $\left.\mathrm{CD}_{3} \mathrm{OD}, \delta=\mathrm{ppm}\right): \delta 9.31(\mathrm{~d}, \mathrm{~J}=2.0 \mathrm{~Hz}, 1 \mathrm{H}), 8.98-8.94(\mathrm{ddd}, \mathrm{J}=8.4,2.0,1.4 \mathrm{~Hz}, 1 \mathrm{H})$, $8.89(\mathrm{~d}, \mathrm{~J}=5.5 \mathrm{~Hz}, 1 \mathrm{H}), 8.22(\mathrm{dd}, \mathrm{J}=8.4,5.7 \mathrm{~Hz}, 1 \mathrm{H}), 8.03(\mathrm{~d}, \mathrm{~J}=9.2 \mathrm{~Hz}, 2 \mathrm{H}), 7.21$ (d, $\mathrm{J}=9.2 \mathrm{~Hz}, 2 \mathrm{H}), 3.76(\mathrm{t}, \mathrm{J}=5.4 \mathrm{~Hz}, 4 \mathrm{H}), 3.41(\mathrm{t}, \mathrm{J}=5.1,5.4 \mathrm{~Hz}, 4 \mathrm{H}) .{ }^{13} \mathrm{C}-\mathrm{NMR}(75 \mathrm{MHz}$, $\left.\mathrm{CD}_{3} \mathrm{OD}, \delta=\mathrm{ppm}\right): \delta 155.3,151.9,146.6,142.7,138.9,138.3,129.3,127.4,116.1,45.7$, 44.4. HRMS m/z calculated for $\mathrm{C}_{15} \mathrm{H}_{18} \mathrm{~N}_{5}: 268.1557\left([\mathrm{M}+\mathrm{H}]^{+}\right)$; found: 268.1562 . 
(6-aminopyridin-3-yl)methanol (4d). A suspension of $\mathrm{LiAlH}_{4}$ in THF (12,0 mmol, $12.0 \mathrm{~mL}$ ) was stirred at $0{ }^{\circ} \mathrm{C}$ under argon atmosphere. To this solution, 3d (10.0 mmol, $1.52 \mathrm{~g})$ in anhydrous THF $(10.0 \mathrm{~mL})$ was added dropwise. The reaction mixture was allowed to warm to r.t. and stirred for $24 \mathrm{~h}$. The system was cooled to $0{ }^{\circ} \mathrm{C}$ and water (3.0 mL) was added slowly, followed by $10 \% \mathrm{NaOH}(3.0 \mathrm{~mL})$, and additional water $(1.5$ $\mathrm{mL}$ ). The salts were removed by filtration through Celite, which was washed several times with THF. The resulting solution was dried over $\mathrm{MgSO}_{4}$ and evaporated by vacuum. The crude was column chromatographed $\left(\mathrm{CH}_{2} \mathrm{Cl}_{2} 75: 25 \mathrm{MeOH}+0.1 \% \mathrm{Et}_{3} \mathrm{~N}\right)$ to give $4 \mathbf{d}$ as a white powder (945.0 mg, $7.61 \mathrm{mmol}, 76 \%) .{ }^{1} \mathrm{H}-\mathrm{NMR}\left(300 \mathrm{MHz}, \mathrm{CD}_{3} \mathrm{OD}, \delta=\mathrm{ppm}\right): \delta$ $7.94(\mathrm{~d}, \mathrm{~J}=8.8 \mathrm{~Hz}, 1 \mathrm{H}), 7.82(\mathrm{~s}, 1 \mathrm{H}), 7.07$ (d, J = 9.0 Hz, 1H) 5.16 (s, 3H), 4.53 (s, 2H). ${ }^{13} \mathrm{C}-\mathrm{NMR}\left(75 \mathrm{MHz}, \mathrm{CD}_{3} \mathrm{OD}, \delta=\mathrm{ppm}\right): \delta 155.2,145.1,133.8,128.1,114.7,60.9$. HRMS $\mathrm{m} / \mathrm{z}$ calculated for $\mathrm{C}_{6} \mathrm{H}_{9} \mathrm{~N}_{2} \mathrm{O}: 125.0709\left([\mathrm{M}+\mathrm{H}]^{+}\right)$; found: 125.0700 .

5-(((tert-butyldimethylsilyl)oxy)methyl)pyridin-2-amine (p-4d). 4d (7.60 mmol, $945.0 \mathrm{mg}$ ) was dissolved in a mixture of $\mathrm{CH}_{2} \mathrm{Cl}_{2}$ :DMF $(50.0 \mathrm{~mL} ; 4: 1)$. The mixture was stirred at $0{ }^{\circ} \mathrm{C}$ and DIPEA (11.4 mmol, $\left.2.00 \mathrm{~mL}\right)$, TBDMSCl (10.6 mmol, $\left.1.60 \mathrm{~g}\right)$, and DMAP $(0.15 \mathrm{mmol}, 18.6 \mathrm{mg})$ were added. The reaction was allowed to warm to r.t., and stirred for $8 \mathrm{~h}$. The solvents were removed by vacuum. The crude was column chromatographed (Hexanes 5:5 AcOEt) to give p-4d as a white powder (968.0 mg, 4.06 mmol, 53\%). ${ }^{1} \mathrm{H}-\mathrm{NMR}\left(300 \mathrm{MHz}, \mathrm{CDCl}_{3}, \delta=\mathrm{ppm}\right): \delta 7.98(\mathrm{~d}, \mathrm{~J}=1.7 \mathrm{~Hz}, 1 \mathrm{H}), 7.40$ (dd, $\mathrm{J}=8.4,2.2 \mathrm{~Hz}, 1 \mathrm{H}), 6.46(\mathrm{~d}, \mathrm{~J}=8.4 \mathrm{~Hz}, 1 \mathrm{H}) 4.57$ (s, 2H), $4.46(\mathrm{~s}, 2 \mathrm{H}), 0.89$ (s, 9H), 0.06 (s, 6H). ${ }^{13} \mathrm{C}-\mathrm{NMR}\left(75 \mathrm{MHz}, \mathrm{CDCl}_{3}, \delta=\mathrm{ppm}\right): \delta 157.9,146.5,137.1,126.7,108.5,62.9$, 26.0, 18.4, -5.1. HRMS m/z calculated for $\mathrm{C}_{12} \mathrm{H}_{23} \mathrm{~N}_{2} \mathrm{OSi}: 239.1574\left([\mathrm{M}+\mathrm{H}]^{+}\right)$; found: 239.1568 .

(E)-5-((tert-butyldimethylsilyl)oxy)methyl)-2-(phenyldiazenyl)pyridine (p-5d). To a solution of p-4d $(2.22 \mathrm{mmol}, 530.0 \mathrm{mg})$ in toluene $(0.88 \mathrm{~mL})$, a solution of $\mathrm{NaOH}$ (26.7 mmol, $1.07 \mathrm{~g}$ ) in $\mathrm{H}_{2} \mathrm{O}(2.20 \mathrm{~mL}$ ) followed by nitrosobenzene (2.67 mmol, 286.0 $\mathrm{mg}$ ) was added. The reactional mixture was vigorously stirred at $50{ }^{\circ} \mathrm{C}$ for $17 \mathrm{~h}$. After cooling to r.t., $\mathrm{H}_{2} \mathrm{O}(1.50 \mathrm{~mL})$ was added and the mixture was extracted with $\mathrm{CH}_{2} \mathrm{Cl}_{2}$ (3 X $20.0 \mathrm{~mL}$ ). The combined organic phases were dried in $\mathrm{Na}_{2} \mathrm{SO}_{4}$, and the solvents removed by vacuum. The crude was column chromatographed (Hexanes 9:1 AcOEt to Hexanes 8:2 AcOEt) to afford p-5d as a red powder (402.0 mg, $1.23 \mathrm{mmol}, 55 \%) .{ }^{1} \mathrm{H}$ NMR (300 MHz, $\left.\mathrm{CDCl}_{3}, \delta=\mathrm{ppm}\right): \delta 8.68(\mathrm{~d}, \mathrm{~J}=1.3 \mathrm{~Hz}, 1 \mathrm{H}), 8.05(\mathrm{~m}, 2 \mathrm{H}), 7.88(\mathrm{dd}, \mathrm{J}$ $=8.2,2.0 \mathrm{~Hz}, 1 \mathrm{H}), 7.83(\mathrm{~d}, \mathrm{~J}=8.1 \mathrm{~Hz}, 1 \mathrm{H}), 7.57-7.52(\mathrm{~m}, 3 \mathrm{H}), 4.86(\mathrm{~s}, 2 \mathrm{H}), 0.95(\mathrm{~s}, 9 \mathrm{H})$, $0.13(\mathrm{~s}, 6 \mathrm{H}) .{ }^{13} \mathrm{C}-\mathrm{NMR}\left(75 \mathrm{MHz}, \mathrm{CDCl}_{3}, \delta=\mathrm{ppm}\right): \delta 162.2,152.6,147.6,138.9,136.3$, 
132.1, 129.3, 115.6, 62.6, 26.0, 18.5, -5.1. HRMS m/z calculated for $\mathrm{C}_{18} \mathrm{H}_{26} \mathrm{~N}_{3} \mathrm{OSi}$ : $328.1840\left([\mathrm{M}+\mathrm{H}]^{+}\right)$; found: 328.1841 .

(E)-(6-(phenyldiazenyl)pyridin-3-yl)methanol (5d). Finally, to a solution of $\mathbf{p - 4 d}$ $(1.23 \mathrm{mmol}, 402.0 \mathrm{mg})$ in THF $(3.80 \mathrm{~mL})$, was added a solution of TBAF in THF (2.45 mmol, $3.7 \mathrm{~mL}$ ). The reactional mixture was stirred at r.t. for $2 \mathrm{~h}$. After completion (monitored by TLC), the reaction was quenched by the addition of saturated solution of $\mathrm{NaHCO}_{3}(3.0 \mathrm{~mL})$. The mixture was then extracted with AcOEt $(2 \times 10.0 \mathrm{~mL})$. The collected organic phase was washed with $\mathrm{H}_{2} \mathrm{O}(2 \times 10.0 \mathrm{~mL})$, followed by Brine $(2 \times 10.0$ $\mathrm{mL}$ ). After drying in $\mathrm{Na}_{2} \mathrm{SO}_{4}$, the solvents were removed by vacuum to afford the $\mathbf{5} \mathbf{d}$ as an orange powder $(236.0 \mathrm{mg}, 1.11 \mathrm{mmol}, 90 \%)$ used in the next step without further purification. ${ }^{1} \mathrm{H}-\mathrm{NMR}\left(300 \mathrm{MHz}, \mathrm{CDCl}_{3}, \delta=\mathrm{ppm}\right): \delta 8.61(\mathrm{~d}, \mathrm{~J}=1.4 \mathrm{~Hz}, 1 \mathrm{H}), 7.98$ (dd, $\mathrm{J}=6.6,2.9 \mathrm{~Hz}, 2 \mathrm{H}), 7.88(\mathrm{dd}, \mathrm{J}=8.2,1.9 \mathrm{~Hz}, 1 \mathrm{H}), 7.75(\mathrm{~d}, \mathrm{~J}=8.2 \mathrm{~Hz}, 1 \mathrm{H}), 7.50(\mathrm{t}, \mathrm{J}=$ 3.6, $2.8 \mathrm{~Hz}, 3 \mathrm{H}), 4.80(\mathrm{~s}, 2 \mathrm{H}), 3.74(\mathrm{~s}, 1 \mathrm{H}) .{ }^{13} \mathrm{C}-\mathrm{NMR}\left(75 \mathrm{MHz}, \mathrm{CDCl}_{3}, \delta=\mathrm{ppm}\right): \delta$ 162.1, 152.4, 147.8, 138.9, 137.2, 129.3, 123.6, 115.1, 62.0. HRMS m/z calculated for $\mathrm{C}_{12} \mathrm{H}_{12} \mathrm{~N}_{3} \mathrm{O}: 214.0975\left([\mathrm{M}+\mathrm{H}]^{+}\right)$; found: 214.0978.

(E)-1-phenyl-2-(p-tolyl)diazene (4e). To a suspension of $\mathbf{3 e}(4.50 \mathrm{mmol}, 482.0$ $\mathrm{mg}$ ) in $\mathrm{AcOH}(5.0 \mathrm{~mL})$ was added a suspension of nitrosobenzene $(4.50 \mathrm{mmol}, 282.0 \mathrm{mg})$ in $\mathrm{AcOH}(5.0 \mathrm{~mL})$. The reaction suspension was stirred vigorously for $24 \mathrm{~h}$ at r.t. The solved was removed by vacuum. The crude compound was column chromatographed (Hexanes 7:3 AcOEt) to afford $4 \mathbf{e}$ as a yellow powder $(822.0 \mathrm{mg}, 4.19 \mathrm{mmol}, 93 \%) .{ }^{1} \mathrm{H}$ NMR (300 MHz, $\left.\mathrm{CDCl}_{3}, \delta=\mathrm{ppm}\right): \delta \delta 7.91(\mathrm{dd}, \mathrm{J}=8.2,1.3 \mathrm{~Hz}, 2 \mathrm{H}), 7.85(\mathrm{~d}, \mathrm{~J}=8.3 \mathrm{~Hz}$, $1 \mathrm{H}), 7.55-7.42(\mathrm{~m}, 3 \mathrm{H}), 7.32(\mathrm{~d}, \mathrm{~J}=8.1 \mathrm{~Hz}, 1 \mathrm{H}), 2.45(\mathrm{~s}, 3 \mathrm{H}) .{ }^{13} \mathrm{C}-\mathrm{NMR}(75 \mathrm{MHz}$, $\left.\mathrm{CD}_{3} \mathrm{OD}, \delta=\mathrm{ppm}\right): \delta 150.9,141.7,130.8,129.9,129.2,123.0,122.9,21.6 . \mathrm{HRMS} \mathrm{m} / \mathrm{z}$ calculated for $\mathrm{C}_{13} \mathrm{H}_{13} \mathrm{~N}_{2}: 197.1073\left([\mathrm{M}+\mathrm{H}]^{+}\right)$; found: 197.1080.

(E)-1-(4-(bromomethyl)phenyl)-2-phenyldiazene (5e).

To a solution of $4 \mathrm{e}(4.19 \mathrm{mmol}, 822.0 \mathrm{mg})$ and NBS $(4.20 \mathrm{mmol}, 748.0 \mathrm{mg})$ in $\mathrm{CCl}_{4}(15.0 \mathrm{~mL})$ was added BPO $(0.006 \mathrm{mmol}, 6.1 \mathrm{mg})$. The reaction mixture was stirred vigorously under reflux and in an atmosphere of argon for $24 \mathrm{~h}$. The solids were filtered off and washed with $\mathrm{CCl}_{4}$. The solvent was removed by vacuum (2 additional traps) to give a mixture of 5e and (E)-[4-(bromomethyl)phenyl]-phenyl-diazene. The crude mixture was column chromatographed (petrolether) to afford the desired azobenzene $\mathbf{5 e}$ as an orange powder $(1.14 \mathrm{~g}, 4.15 \mathrm{mmol}, 99 \%)$ used in the next step without further purification. ${ }^{1} \mathrm{H}-\mathrm{NMR}\left(300 \mathrm{MHz}, \mathrm{CDCl}_{3}, \delta=\mathrm{ppm}\right): \delta$ 7.95-7.92 (m, 4H), 7.57-7.46 (m, $5 \mathrm{H}), 4.56$ (s, 2H). ${ }^{13} \mathrm{C}-\mathrm{NMR}\left(75 \mathrm{MHz}, \mathrm{CD}_{3} \mathrm{OD}, \delta=\mathrm{ppm}\right): \delta 152.7,152.5,140.6,131.4$, 
130.0, 129.2, 123.4, 123.1, 32.9. HRMS m/z calculated for $\mathrm{C}_{13} \mathrm{H}_{12} \mathrm{BrN}_{2}: 275.0178$ $\left([\mathrm{M}+\mathrm{H}]^{+}\right)$; found: 275.0179 .

1-(4-phenylcyclohexyl)piperazine, double hydrochloride salt (8). To a solution of 4-phenylcyclohexanone (6,10.0 mmol, $1.74 \mathrm{~g})$ and tert-butyl piperazine-1-carboxylate $(11.0 \mathrm{mmol}, 2.05 \mathrm{~g})$ in dry DCE $(20.0 \mathrm{~mL})$, was added AcOH $(1.75 \mathrm{mmol}, 0.10 \mathrm{~mL})$. The reaction mixture was stirred at r.t. for $6 \mathrm{~h}$. After complete consumption of the amine (TLC), $\mathrm{NaBH}(\mathrm{OAc})_{3}(13.0 \mathrm{mmol}, 2.75 \mathrm{~g})$ was added in small portions. The mixture was stirred for $48 \mathrm{~h}$ at r.t. The reaction was quenched by addition of saturated solution of $\mathrm{NaHCO}_{3}(20.0 \mathrm{~mL})$. The mixture was extracted with $\mathrm{CH}_{2} \mathrm{Cl}_{2}(3 \times 20.0 \mathrm{~mL})$. The organic phase was collected and extracted with an aqueous solution of $\mathrm{HCl}(1 \mathrm{M} ; 3$ × $20.0 \mathrm{~mL})$ and was washed with $\mathrm{H}_{2} \mathrm{O}(1 \times 20.0 \mathrm{~mL})$. The resulting organic phase was dried in $\mathrm{Na}_{2} \mathrm{SO}_{4}$, and the solvent was removed by vacuum to afford the desired boc-protected amine as a white powder and was used in the next step without further purification. The amine was refluxed $\left(90^{\circ} \mathrm{C}\right)$ in an aqueous $\mathrm{HCl}$ solution $(2,0 \mathrm{M} ; 35.0 \mathrm{~mL})$ for $90 \mathrm{~min}$. The solvent was partially removed by vacuum. The resulting solution was diluted with $\mathrm{H}_{2} \mathrm{O}$ (10.0 $\mathrm{mL})$ and lyophilized to afford 8 as a mixture of diastereomers of 1-(4phenylcyclohexyl)piperazine (white powder, $2.79 \mathrm{~g}, 8.78 \mathrm{mmol}, 88 \%$ ) used in the next step without further purification. ${ }^{1} \mathrm{H}-\mathrm{NMR}\left(300 \mathrm{MHz}, \mathrm{D}_{2} \mathrm{O}, \delta=\mathrm{ppm}\right): \delta$ 7.37-7.24 (m, 5H), 3.74-3.43 (m, 9H), $2.84(\mathrm{~s}, 1 \mathrm{H}), 2.25-1.30(\mathrm{~m}, 8 \mathrm{H}) .{ }^{13} \mathrm{C}-\mathrm{NMR}\left(75 \mathrm{MHz}, \mathrm{CDCl}_{3}, \delta=\right.$ ppm): $\delta 145.8,144.3,128.7,127.4,126.9,126.2,65.8,65.4,46.0,45.5,41.0,40.5,37.9$, 31.6, 27.3, 26.4, 23.5. HRMS m/z calculated for $\mathrm{C}_{16} \mathrm{H}_{25} \mathrm{~N}_{2}: 245.2012\left([\mathrm{M}+\mathrm{H}]^{+}\right)$; found: 245.2011 .

\section{1-((1S,4S)-4-phenylcyclohexyl)-4-(6-((E)-phenyldiazenyl)pyridin-3-}

yl)piperazine, double hydrochloride salt (9a). To a solution of $\mathbf{5 a}(1.10 \mathrm{mmol}, 374.2 \mathrm{mg})$ and 6 (1.00 mmol, $174.2 \mathrm{mg})$ in dry DCE (5.00 mL) was added $\mathrm{Et}_{3} \mathrm{~N}(2.10 \mathrm{mmol}, 0.292$ $\mathrm{mL})$. The solution was stirred vigorously at r.t. for $3 \mathrm{~h}$. $\mathrm{NaBH}(\mathrm{OAc})_{3}(1.30 \mathrm{mmol}, 274.3$ $\mathrm{mg}$ ) was added in small portions and the mixture was stirred for 2 days at r.t. The solvent was removed in vacuum. The crude was subjected to column chromatography (Hexanes 7:3 AcOEt $+0.5 \% \mathrm{Et}_{3} \mathrm{~N}$ to Hexanes 5:5 AcOEt $\left.+0.5 \% \mathrm{Et}_{3} \mathrm{~N}\right)$. The title compound was solubilized in a mixture a methanolic solution of $\mathrm{HCl}(1.25 \mathrm{M})$ and precipitated by the addition of dry diethylether to afford 9a as an orange powder $(198.8 \mathrm{mg}, 0.40 \mathrm{mmol}$, 40\%). ${ }^{1} \mathrm{H}-\mathrm{NMR}\left(300 \mathrm{MHz}, \mathrm{C}_{6} \mathrm{D}_{6}, \delta=\mathrm{ppm}\right): \delta 8.41(\mathrm{~d}, J=3.0 \mathrm{~Hz}, 1 \mathrm{H}), 8.23-8.19(\mathrm{~m}$, 2H), $7.94(\mathrm{~d}, J=9.0 \mathrm{~Hz}, 1 \mathrm{H}), 7.31-7.23(\mathrm{~m}, 4 \mathrm{H}), 7.21-7.05(\mathrm{~m}, 8 \mathrm{H}), 6.77(\mathrm{dd}, J=9.0$, $3.1 \mathrm{~Hz}, 1 \mathrm{H}), 2.79(\mathrm{t}, \mathrm{J}=5.2,5.0 \mathrm{~Hz}, 4 \mathrm{H}), 2.54(\mathrm{tt}, J=11.0,3.9 \mathrm{~Hz}, 1 \mathrm{H}), 2.17(\mathrm{t}, \mathrm{J}=5.2$, 
5.0 Hz, 4H), 2.01-1.99 (m, 1H), 1.93-1.77 (m, 4H), 1.57-1.51 (m, 2H), 1.34-1.26 (m, 2H). ${ }^{1} \mathrm{H}-\mathrm{NMR}\left(300 \mathrm{MHz}, \mathrm{CD}_{3} \mathrm{OD}, \delta=\mathrm{ppm}\right): \delta 8.53(\mathrm{~d}, J=2.9 \mathrm{~Hz}, 1 \mathrm{H}), 8.30(\mathrm{~d}, J=9.4 \mathrm{~Hz}$, $1 \mathrm{H}), 8.22(\mathrm{dd}, J=9.5,2.9 \mathrm{~Hz}, 1 \mathrm{H}), 8.06$ (dt, $J=3.9,2.6 \mathrm{~Hz}, 2 \mathrm{H}), 7.70-7.59$ (m, 3h), 7.42 $(\mathrm{d}, J=7.5 \mathrm{~Hz}, 2 \mathrm{H}), 7.32(\mathrm{t}, J=7.6 \mathrm{~Hz}, 2 \mathrm{H}), 7.18(\mathrm{t}, J=7.3 \mathrm{~Hz}, 1 \mathrm{H}), 4.33(\mathrm{~d}, J=14.2 \mathrm{~Hz}$, 2H), $3.83(\mathrm{~d}, J=12.6 \mathrm{~Hz}, 2 \mathrm{H}), 3.73(\mathrm{t}, J=13.2 \mathrm{~Hz}, 2 \mathrm{H}), 3.51(\mathrm{dt}, J=7.4,3.7 \mathrm{~Hz}, 1 \mathrm{H})$, 3.37 (dd, $J=12.2,2.4 \mathrm{~Hz}, 1 \mathrm{H}), 2.99$ (dd, $J=8.7,5.1 \mathrm{~Hz}, 1 \mathrm{H}), 2.38-2.29$ (m, 2H), 2.12$1.86(\mathrm{~m}, 6 \mathrm{H}) .{ }^{13} \mathrm{C}-\mathrm{NMR}\left(75 \mathrm{MHz}, \mathrm{C}_{6} \mathrm{D}_{6}, \delta=\mathrm{ppm}\right): \delta 156.9,153.6,147.9,147.7,136.4$, $130.9,129.3,128.8,127.3,126.4,123.6,121.7,113.4,58.2,49.5,47.5,44.2,28.6 .{ }^{13} \mathrm{C}-$ $\operatorname{NMR}\left(75 \mathrm{MHz}, \mathrm{CD}_{3} \mathrm{OD}, \delta=\mathrm{ppm}\right): \delta 153.5,149.6,144.5,135.2,131.1,130.8,129.6$, 128.7, 128.3, 127.1, 125.0, 120.0, 66.3, 45.1, 39.6, 29.1, 25.0. HRMS m/z calculated for $\mathrm{C}_{27} \mathrm{H}_{32} \mathrm{~N}_{5}: 426.2652\left([\mathrm{M}+\mathrm{H}]^{+}\right)$; found: 426.2637.

1-((1S,4S)-4-phenylcyclohexyl)-4-(4-((E)-phenyldiazenyl)phenyl)piperazine, hydrochloride salt $(\mathbf{9 b})$. To a solution of $\mathbf{5 b}(1.85 \mathrm{mmol}, 560.0 \mathrm{mg})$ and $\mathbf{6}(1.68 \mathrm{mmol}$, $293.0 \mathrm{mg})$ in dry DCE $(9.20 \mathrm{~mL})$ was added $\mathrm{Et}_{3} \mathrm{~N}(3.60 \mathrm{mmol}, 0.501 \mathrm{~mL})$. The solution was stirred vigorously at r.t. for $6 \mathrm{~h}$. $\mathrm{NaBH}(\mathrm{OAc})_{3}(2.19 \mathrm{mmol}, 464.0 \mathrm{mg})$ was added in small portions and the mixture was stirred for 2 days at r.t. The reaction was stopped by the addition of saturated solution of $\mathrm{NaHCO}_{3}(50.0 \mathrm{~mL})$. The mixture was extracted with $\mathrm{CH}_{2} \mathrm{Cl}_{2}(5 \times 50.0 \mathrm{~mL})$, the collected organic phase was washed with $\mathrm{H}_{2} \mathrm{O}(2 \times 50.0 \mathrm{~mL})$, dried in $\mathrm{Na}_{2} \mathrm{SO}_{4}$, and the solvent was removed in vacuum. The crude was subjected to column chromatography (Hexanes 7:3 AcOEt $+0.5 \% \mathrm{Et}_{3} \mathrm{~N}$ ). The title compound was solubilized in a mixture a methanolic solution of $\mathrm{HCl}(1.25 \mathrm{M})$ and precipitated by the addition of dry diethylether to afford $\mathbf{9 b}$ as a red powder (261.0 $\mathrm{mg}, 0.56 \mathrm{mmol}, 34 \%)$. ${ }^{1} \mathrm{H}-\mathrm{NMR}\left(300 \mathrm{MHz}, \mathrm{C}_{6} \mathrm{D}_{6}, \delta=\mathrm{ppm}\right): \delta 8.23$ (d, J = 9.0 Hz, 2H), 8.16 (dd, J =7.3, $1.3 \mathrm{~Hz}$, 2H), 7.31-7.22 (m, 6H), 7.14-7.08 (m, 2H), $6.75(\mathrm{~d}, \mathrm{~J}=9.1 \mathrm{~Hz}, 2 \mathrm{H}), 2.93(\mathrm{t}, \mathrm{J}=10.1,5.0$ $\mathrm{Hz}, 4 \mathrm{H}), 2.55(\mathrm{tt}, \mathrm{J}=11.0,3.8 \mathrm{~Hz}, 1 \mathrm{H}), 2.26(\mathrm{t}, \mathrm{J}=10.1,5.0 \mathrm{~Hz}, 4 \mathrm{H}), 2.03(\mathrm{t}, \mathrm{J}=5.8,2.9$ $\mathrm{Hz}, 1 \mathrm{H}), 1.96-1.82(\mathrm{~m}, 4 \mathrm{H}), 1.55$ (dd, J = 12.9, $3.6 \mathrm{~Hz}, 1 \mathrm{H}), 1.31$ (t, J = 13.1 Hz, 2H). ${ }^{13} \mathrm{C}-\mathrm{NMR}\left(75 \mathrm{MHz}, \mathrm{C}_{6} \mathrm{D}_{6}, \delta=\mathrm{ppm}\right): \delta 153.9,153.6,147.7,146.1,130.0,129.3,128.8$, $128.3,127.3,126.4,125.3,123.0,114.7,58.3,49.8,48.1,44.3,28.7$. HRMS m/z calculated for $\mathrm{C}_{28} \mathrm{H}_{33} \mathrm{~N}_{4}: 425.2700\left([\mathrm{M}+\mathrm{H}]^{+}\right)$; found: 425.2698 .

1-((1S,4S)-4-phenylcyclohexyl)-4-(4-((E)-pyridin-3-

yldiazenyl)phenyl)piperazine, double hydrochloride salt (9c). To a solution of 5c (2.20 mmol, $750.0 \mathrm{mg})$ and $6(2.00 \mathrm{mmol}, 348.0 \mathrm{mg})$ in dry DCE $(10.00 \mathrm{~mL})$ was added $\mathrm{Et}_{3} \mathrm{~N}$ $(4.80 \mathrm{mmol}, 0.669 \mathrm{~mL})$. The solution was stirred vigorously at r.t. for $3 \mathrm{~h}$. $\mathrm{NaBH}(\mathrm{OAc})_{3}$ $(2.60 \mathrm{mmol}, 551.0 \mathrm{mg})$ was added in small portions and the mixture was stirred for 2 days 
at r.t. The reaction was quenched by the addition of saturated solution of $\mathrm{NaHCO}_{3}(50.0$ $\mathrm{mL})$. The mixture was extracted with $\mathrm{CH}_{2} \mathrm{Cl}_{2}(5 \times 50.0 \mathrm{~mL})$. The collected organic phase was washed with $\mathrm{H}_{2} \mathrm{O}(2 \times 50.0 \mathrm{~mL})$, dried over $\mathrm{Na}_{2} \mathrm{SO}_{4}$, and the solvents were evaporated under vacuum. The crude was subjected to column chromatography (Hexanes 7:3 AcOEt $+0.5 \% \mathrm{Et}_{3} \mathrm{~N}$ to Hexanes 3:7 $\left.\mathrm{AcOEt}+0.5 \% \mathrm{Et}_{3} \mathrm{~N}\right)$. The title compound was solubilized in a mixture a methanol solution of $\mathrm{HCl}(1.25 \mathrm{M})$ and precipitated by the addition of dry diethylether to afford 9c as a red powder (397.0 mg, $0.80 \mathrm{mmol}, 40 \%)$. ${ }^{1} \mathrm{H}-\mathrm{NMR}\left(300 \mathrm{MHz}, \mathrm{C}_{6} \mathrm{D}_{6}, \delta=\mathrm{ppm}\right): \delta 9.57(\mathrm{~d}, \mathrm{~J}=2.1 \mathrm{~Hz}, 1 \mathrm{H}), 8.50(\mathrm{dd}, \mathrm{J}=4.7,1.6 \mathrm{~Hz}$, $1 \mathrm{H}), 8.15(\mathrm{dt}, \mathrm{J}=6.9,3.1,2.0 \mathrm{~Hz}, 2 \mathrm{H}), 8.02(\mathrm{ddd}, \mathrm{J}=8.1,2.3,1.7 \mathrm{~Hz}, 1 \mathrm{H}), 7.31-7.24(\mathrm{~m}$, $5 \mathrm{H}), 6.77$ (ddd, $\mathrm{J}=8.1,4.7,0.6 \mathrm{~Hz}, 1 \mathrm{H}), 6.72(\mathrm{dt}, \mathrm{J}=9.2,3.0,1.9 \mathrm{~Hz}, 2 \mathrm{H}) 2.94(\mathrm{t}, \mathrm{J}=$ 10.2, $5.0 \mathrm{~Hz}, 4 \mathrm{H}), 2.55(\mathrm{tt}, \mathrm{J}=11.0,3.9 \mathrm{~Hz}, 1 \mathrm{H}), 2.25(\mathrm{~d}, \mathrm{~J}=10.2,5.1 \mathrm{~Hz}, 4 \mathrm{H}), 2.03$ (t, J $=5.6,2.8 \mathrm{~Hz}, 1 \mathrm{H}), 1.94(\mathrm{ddd}, \mathrm{J}=9.6,2.8,1.6 \mathrm{~Hz}, 2 \mathrm{H}), 1,85-1.81(\mathrm{~m}, 2 \mathrm{H}), 1.57-1.53(\mathrm{~m}$, 2H), 1.36-1.28 (m, 2H). ${ }^{13} \mathrm{C}-\mathrm{NMR}$ (75 MHz, $\left.\mathrm{C}_{6} \mathrm{D}_{6}, \delta=\mathrm{ppm}\right): \delta 153.9,151.1,148.8,147.7$, 147.6, 145.9, 128.8, 127.3, 126.4, 126.2, 125.5, 123.8, 114.5, 58.4, 49.8, 47.9, 44.2, 28.7. HRMS m/z calculated for $\mathrm{C}_{27} \mathrm{H}_{32} \mathrm{~N}_{5}: 426.2652\left([\mathrm{M}+\mathrm{H}]^{+}\right)$; found: 426.2652 .

1-((1S,4S)-4-phenylcyclohexyl)-4-((6-((E)-phenyldiazenyl)pyridin-3yl)methyl)piperazine, triple hydrochloride salt $(\mathbf{9 d})$. A solution of $\mathbf{5 d}(0.67 \mathrm{mmol}, 143.6$ $\mathrm{mg})$ and $\mathrm{Et}_{3} \mathrm{~N}(2.14 \mathrm{mmol}, 0.298 \mathrm{~mL})$ in THF $(6.4 \mathrm{~mL})$ was cooled to $0{ }^{\circ} \mathrm{C}$, under stirring. $\mathrm{MsCl}(1.34 \mathrm{mmol}, 0.104 \mathrm{~mL})$ was added dropwise over a period of 5 minutes. After addition, the mixture stirred for additional 10 minutes at $0{ }^{\circ} \mathrm{C}$. the ice bath was removed and the mixture was allowed to warm to r.t. and stirred for $2 \mathrm{~h}$. After complete consumption of the starting materials (monitored by TLC) the reaction mixture was filtered through Celite, washed several times with THF, and concentrated in vacuum. Ms5d was obtained as an orange oil $(195.2 \mathrm{mg})$ and was used in the next step without further purification. Then, Ms-5d (0.67 mmol, $195.2 \mathrm{mg}), 8$ (0.80 mmol, $224.7 \mathrm{mg}), \mathrm{K}_{2} \mathrm{CO}_{3}(2.00$ mmol, $276.4 \mathrm{mg})$, and $\mathrm{NaI}(0.07 \mathrm{mmol}, 10.5 \mathrm{mg})$ were suspended in DMF (2.5 mL) and stirred at $60{ }^{\circ} \mathrm{C}$ for $2 \mathrm{~h}$. After completion (monitored by TLC), the reaction was partially concentrated under vacuum and diluted with AcOEt $(20.0 \mathrm{~mL})$. The solution was filtered over a pad of silica (Hexanes 5:5 AcOEt), and the solvents were evaporated. $\mathrm{H}_{2} \mathrm{O}(25.0$ $\mathrm{mL}$ ) was added to the crude and the suspension was extracted with AcOEt ( 3 x $25.0 \mathrm{~mL})$. The collected organic phase was extracted with an aqueous solution of $\mathrm{HCl}(1.0 \mathrm{M}, 2 \mathrm{x}$ $25.0 \mathrm{~mL}$ ). The resulting aqueous phase was neutralized with saturated solution of $\mathrm{NaHCO}_{3}$ and extracted with AcOEt $(2 \times 25.0 \mathrm{~mL})$. The combined organic phases was dried over $\mathrm{Na}_{2} \mathrm{SO}_{4}$ and evaporated under vacuum. The crude was column 
chromatographed (Hexanes 5:5 AcOEt $\left.+0.5 \% \mathrm{Et}_{3} \mathrm{~N}\right)$. The title compound was solubilized in a mixture a methanolic solution of $\mathrm{HCl}(1.25 \mathrm{M})$ to afford $9 \mathbf{d}$ as a red powder $(75.0$ $\mathrm{mg}, 0.14 \mathrm{mmol}, 20 \%) .{ }^{1} \mathrm{H}-\mathrm{NMR}\left(300 \mathrm{MHz}, \mathrm{C}_{6} \mathrm{D}_{6}, \delta=\mathrm{ppm}\right): \delta 8.74(\mathrm{~d}, J=1.8 \mathrm{~Hz}, 1 \mathrm{H})$, $8.12(\mathrm{dd}, \mathrm{J}=6.9,1.5 \mathrm{~Hz}, 2 \mathrm{H}), 7.69(\mathrm{~d}, J=8.2 \mathrm{~Hz}, 1 \mathrm{H}), 7.50(\mathrm{dd}, J=8.2,2.2 \mathrm{~Hz}, 1 \mathrm{H})$, 7.30-7.20 (m, 4H), 7.13-7.04 (m, 4H), $3.13(\mathrm{~s}, 2 \mathrm{H}), 2.53(\mathrm{tt}, \mathrm{J}=11.0,7.9,3.8 \mathrm{~Hz}, 1 \mathrm{H})$, $2.30(\mathrm{~d}, J=15.0 \mathrm{~Hz}, 8 \mathrm{H}), 2.09$ (t, $J=2.5 \mathrm{~Hz}, 1 \mathrm{H}), 1.95(\mathrm{ddd}, J=29.4,15.4,2.0 \mathrm{~Hz}, 4 \mathrm{H})$, $1.54(\mathrm{dd}, J=12.8,3.6 \mathrm{~Hz}, 2 \mathrm{H}), 1.32$ (t, $J=13.0 \mathrm{~Hz}, 2 \mathrm{H}) .{ }^{1} \mathrm{H}-\mathrm{NMR}(300 \mathrm{MHz}$, DMSO$\left.d_{6}, \delta=\mathrm{ppm}\right): \delta 11.54(\mathrm{bs}, 1 \mathrm{H}), 8.97(\mathrm{~d}, J=1.7 \mathrm{~Hz}, 1 \mathrm{H}), 8.38(\mathrm{dd}, J=8.3,2.1 \mathrm{~Hz}, 1 \mathrm{H})$, $7.97(\mathrm{dt}, J=7.6,3.4 \mathrm{~Hz}, 2 \mathrm{H}), 7.80(\mathrm{~d}, J=8.2 \mathrm{~Hz}, 1 \mathrm{H}), 7.67(\mathrm{dd}, J=6.6,3.6 \mathrm{~Hz}, 3 \mathrm{H})$, $7.43(\mathrm{~d}, J=7.4 \mathrm{~Hz}, 2 \mathrm{H}), 7.28(\mathrm{t}, J=7.5 \mathrm{~Hz}, 2 \mathrm{H}), 7.17(\mathrm{t}, J=7.3 \mathrm{~Hz}, 1 \mathrm{H}), 5.56(\mathrm{~s}, 4 \mathrm{H})$, 4.59 (s, 2H), $3.80(\mathrm{t}, J=15.0 \mathrm{~Hz}, 4 \mathrm{H}), 3.65-3.34(\mathrm{~m}, 5 \mathrm{H}), 2.80-2.74(\mathrm{~m}, 1 \mathrm{H}), 2.25-2.18$ $(\mathrm{m}, 2 \mathrm{H}), 1.94-1.81(\mathrm{~m}, 2 \mathrm{H}), 1.67(\mathrm{~d}, J=10.7 \mathrm{~Hz}, 1 \mathrm{H}) .{ }^{13} \mathrm{C}-\mathrm{NMR}\left(75 \mathrm{MHz}, \mathrm{C}_{6} \mathrm{D}_{6}, \delta=\right.$ ppm): $\delta 163.8,153.2,150.4,147.8,138.3,136.4,131.9,129.4,128.7,127.3,126.3,123.8$, 112.6, 59.9, 58.7, 54.0, 50.3, 44.3, 28.8, 28.7. HRMS m/z calculated for $\mathrm{C}_{28} \mathrm{H}_{34} \mathrm{~N}_{5}$ : $440.2809\left([\mathrm{M}+\mathrm{H}]^{+}\right)$; found: 440.2796 .

1-((1S,4S)-4-phenylcyclohexyl)-4-(4-((E)-phenyldiazenyl)benzyl)piperazine, double hydrochloride salt $(\mathbf{9 e}) . \mathrm{K}_{2} \mathrm{CO}_{3}(6.00 \mathrm{mmol}, 829.0 \mathrm{mg})$ was added to a stirring solution of $5 \mathrm{e}(1.50 \mathrm{mmol}, 413.0 \mathrm{mg})$ and $\mathbf{8}(1.50 \mathrm{mmol}, 367.0 \mathrm{mg})$ in DMF (10.00 mL). The solution was stirred vigorously at r.t. for $24 \mathrm{~h}$. The reaction was quenched by the addition of $\mathrm{H}_{2} \mathrm{O}(50.0 \mathrm{~mL})$. The precipitates were collected and washed with $\mathrm{H}_{2} \mathrm{O}$. After removal of the residual solvent under vacuum, the crude was subjected to column chromatography (Hexanes 5:5 AcOEt $\left.+0.5 \% \mathrm{Et}_{3} \mathrm{~N}\right)$. The title compound was solubilized in a mixture a methanol solution of $\mathrm{HCl}(1.25 \mathrm{M})$ and precipitated by the addition of dry diethylether to afford 9e as a orange powder (350.0 mg, $0.68 \mathrm{mmol}, 46 \%)$. ${ }^{1} \mathrm{H}-\mathrm{NMR}(300$ $\left.\mathrm{MHz}, \mathrm{C}_{6} \mathrm{D}_{6}, \delta=\mathrm{ppm}\right): \delta 8.12-8.05(\mathrm{~m}, 4 \mathrm{H}), 7.43(\mathrm{~d}, \mathrm{~J}=8.4 \mathrm{~Hz}, 2 \mathrm{H}), 7.30-7.19(\mathrm{~m}, 6 \mathrm{H})$, 7.10 (ddt, J = 7.2, 4.6, 1.4 Hz, 2H), 3.33 (s, 2H), 2.53 (tt, J = 11.1, 7.8, 3.8 Hz, 1H), 2.40 $(\mathrm{s}, 8 \mathrm{H}), 2.11(\mathrm{t}, \mathrm{J}=5.9,2.9 \mathrm{~Hz}, 1 \mathrm{H}), 2.05-1.86(\mathrm{~m}, 4 \mathrm{H}), 1.56-1.51(\mathrm{~m}, 2 \mathrm{H}), 1.36-1.26(\mathrm{~m}$, $2 \mathrm{H}) .{ }^{13} \mathrm{C}-\mathrm{NMR}\left(75 \mathrm{MHz}, \mathrm{C}_{6} \mathrm{D}_{6}, \delta=\mathrm{ppm}\right): \delta$ 153.4, 152.6, 147.9, 142.9, 131.0, 129.9, $129.3,128.7,127.4,126.2,123.4,123.3,62.9,58.7,54.1,50.4,44.4,28.9,28.7$. HRMS $\mathrm{m} / \mathrm{z}$ calculated for $\mathrm{C}_{29} \mathrm{H}_{35} \mathrm{~N}_{4}: 439.2856\left([\mathrm{M}+\mathrm{H}]^{+}\right)$; found: 439.2844 . 


\section{Copy of ${ }^{1} \mathrm{H}$ and ${ }^{13} \mathrm{C}$ NMR spectra}

(E)-1-(6-(phenyldiazenyl)pyridin-3-yl)piperazine, double hydrochloride salt (5a)

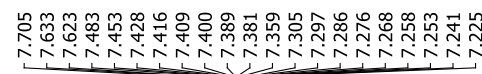
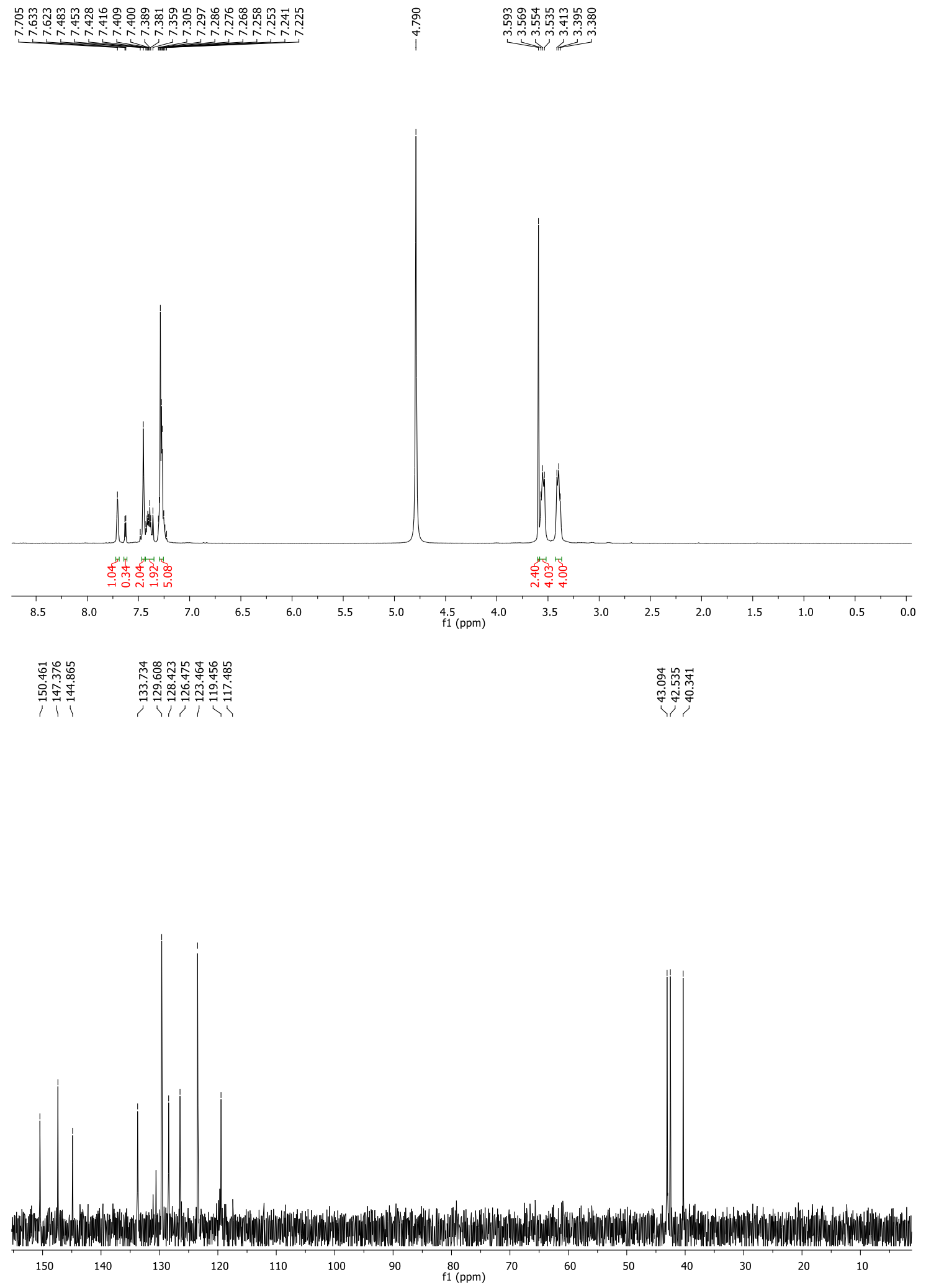
(E)-1-(4-(phenyldiazenyl)phenyl)piperazine, hydrochloride salt (5b)

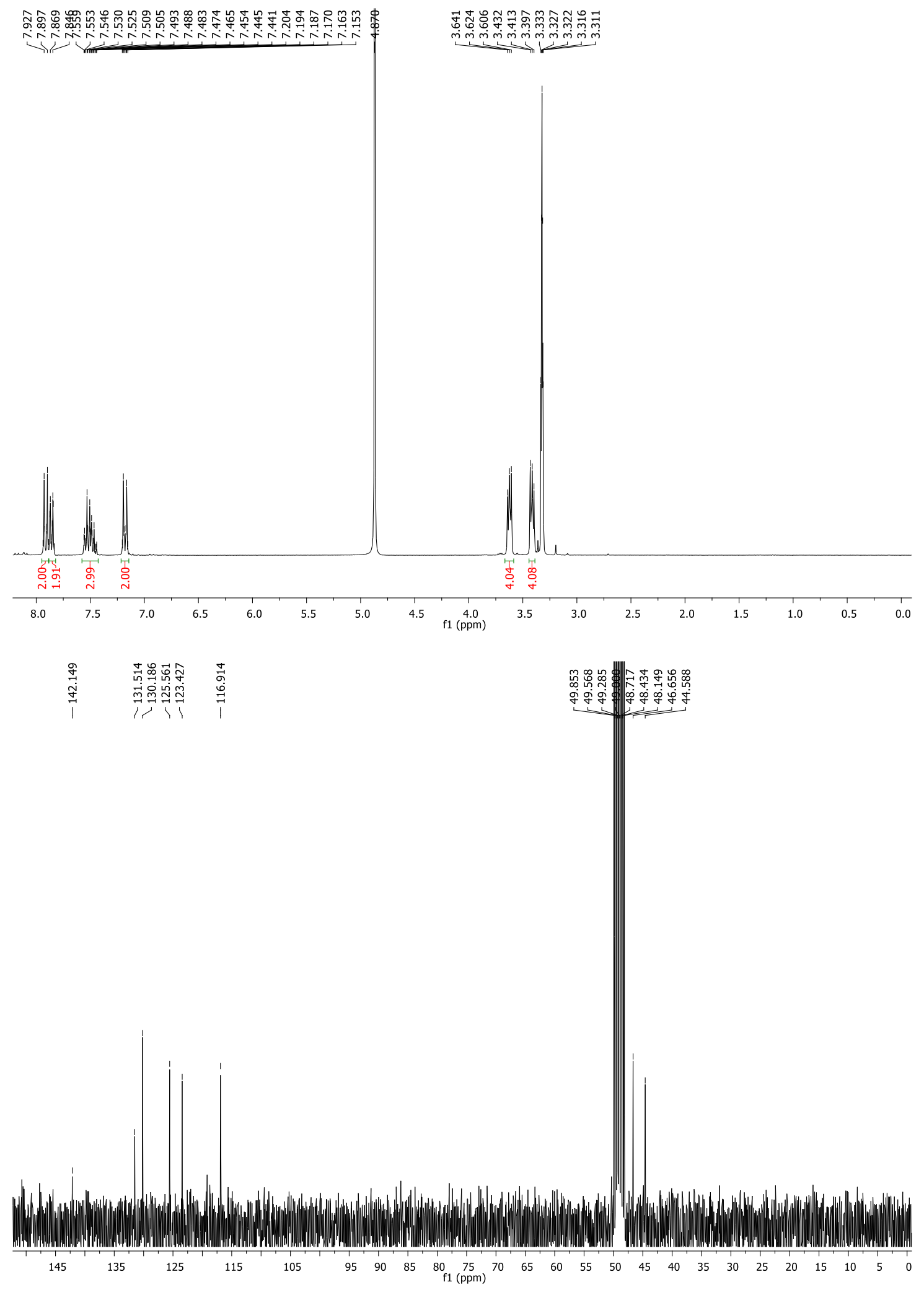


(E)-(4-piperazin-1-ylphenyl)-(3-pyridyl)diazene, double hydrochloride salt (5c)

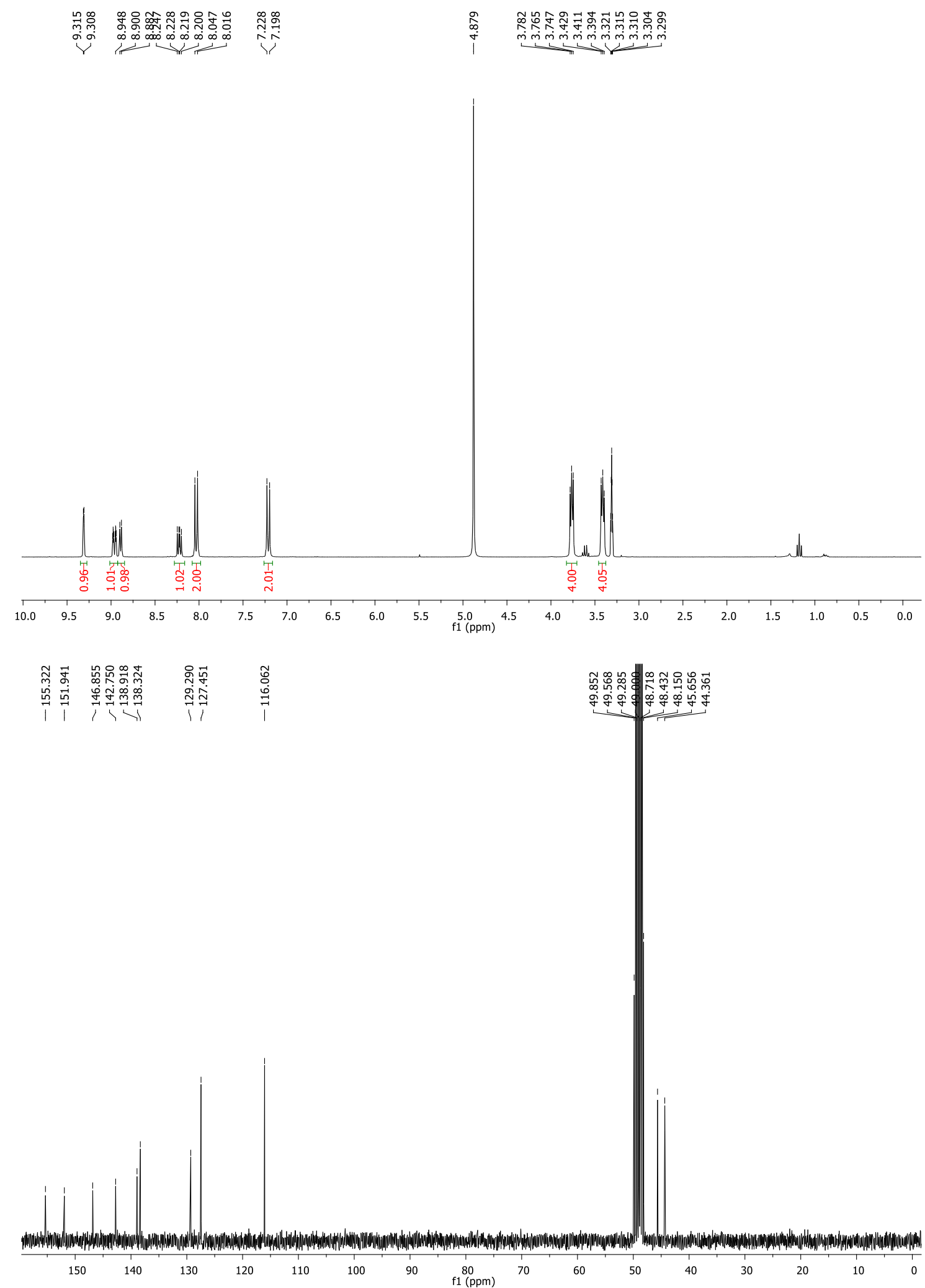


(6-aminopyridin-3-yl)methanol (4d)

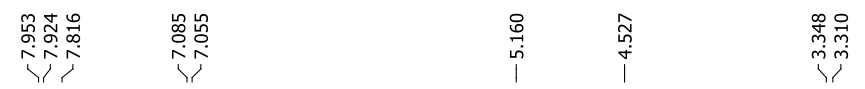

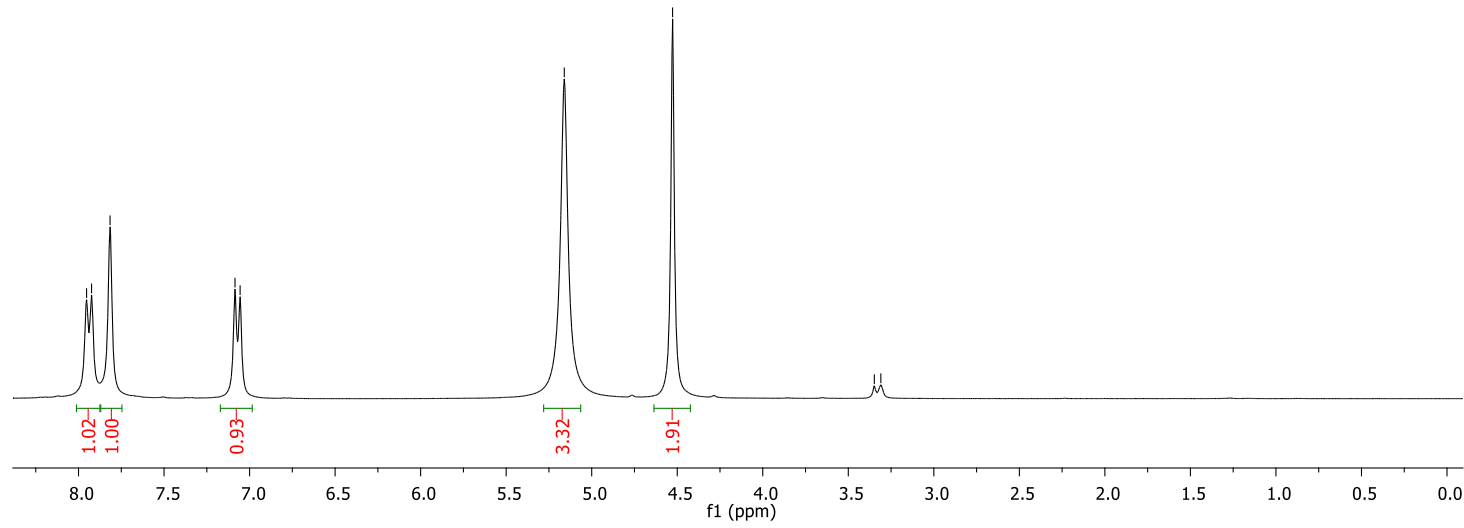

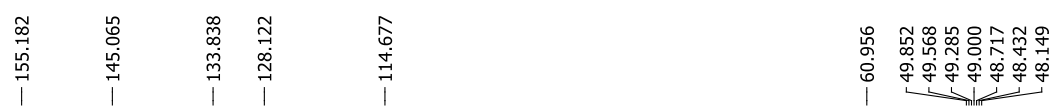

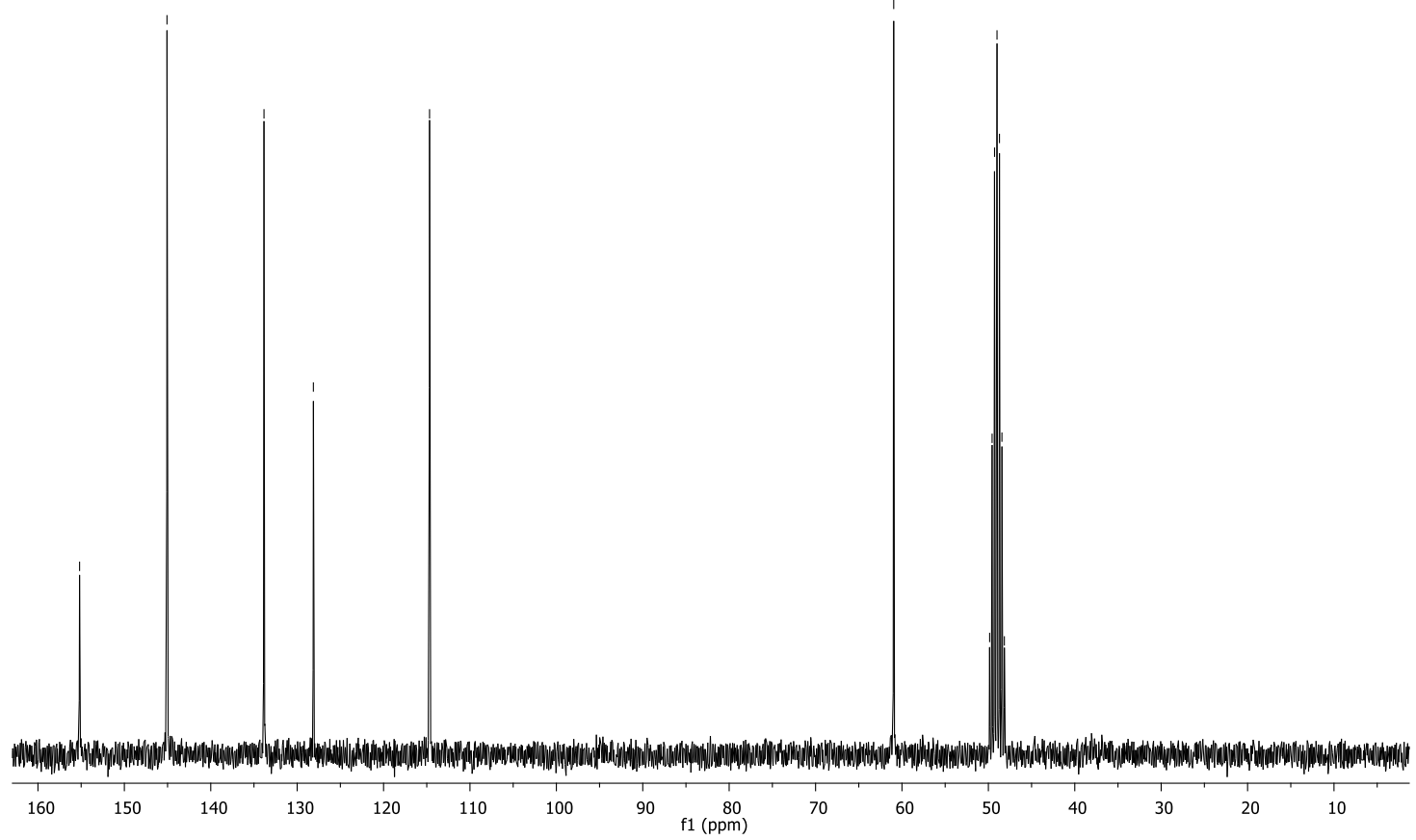


5-(((tert-butyldimethylsilyl)oxy)methyl)pyridin-2-amine (p-4d)
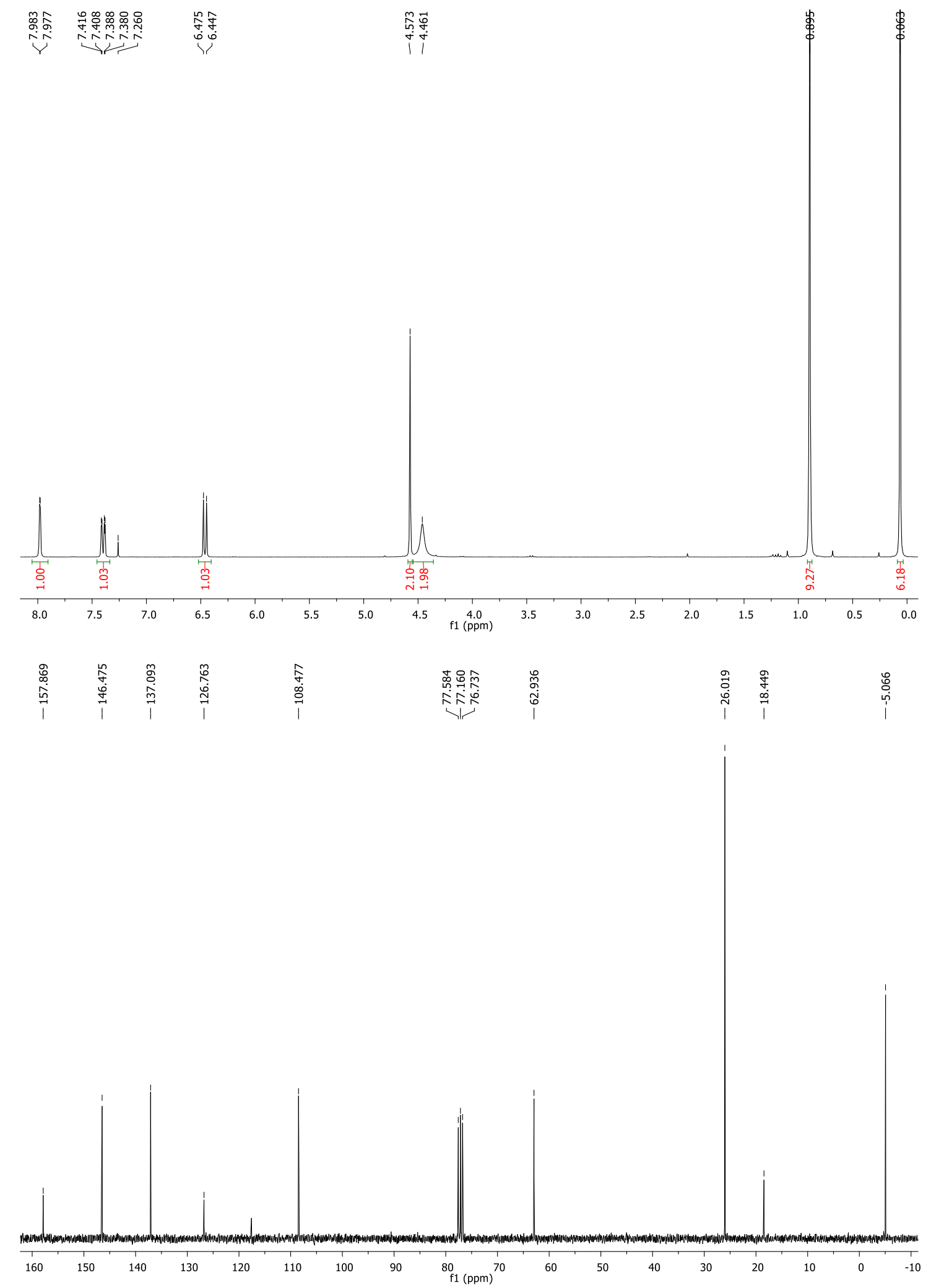
(E)-5-(((tert-butyldimethylsilyl)oxy)methyl)-2-(phenyldiazenyl)pyridine (p-5d)

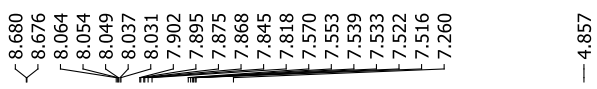

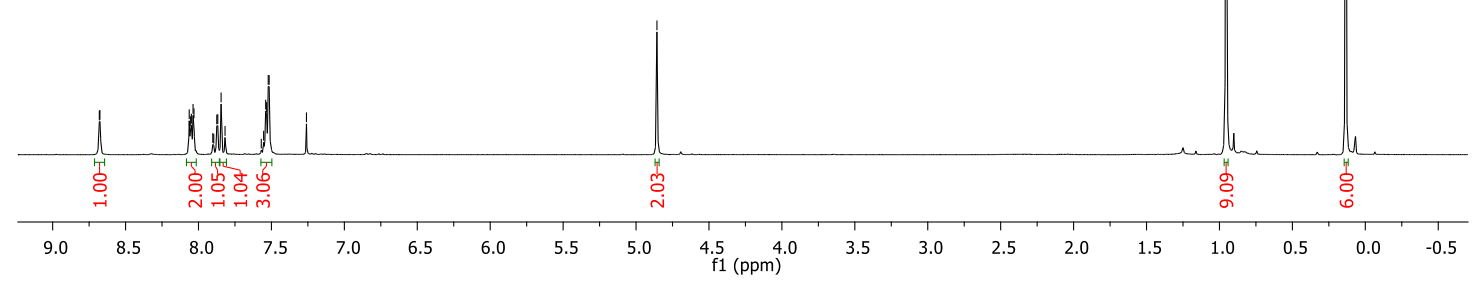

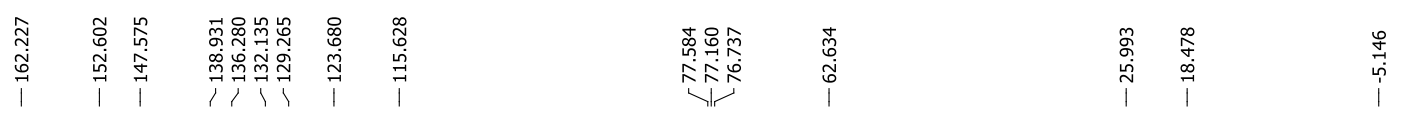

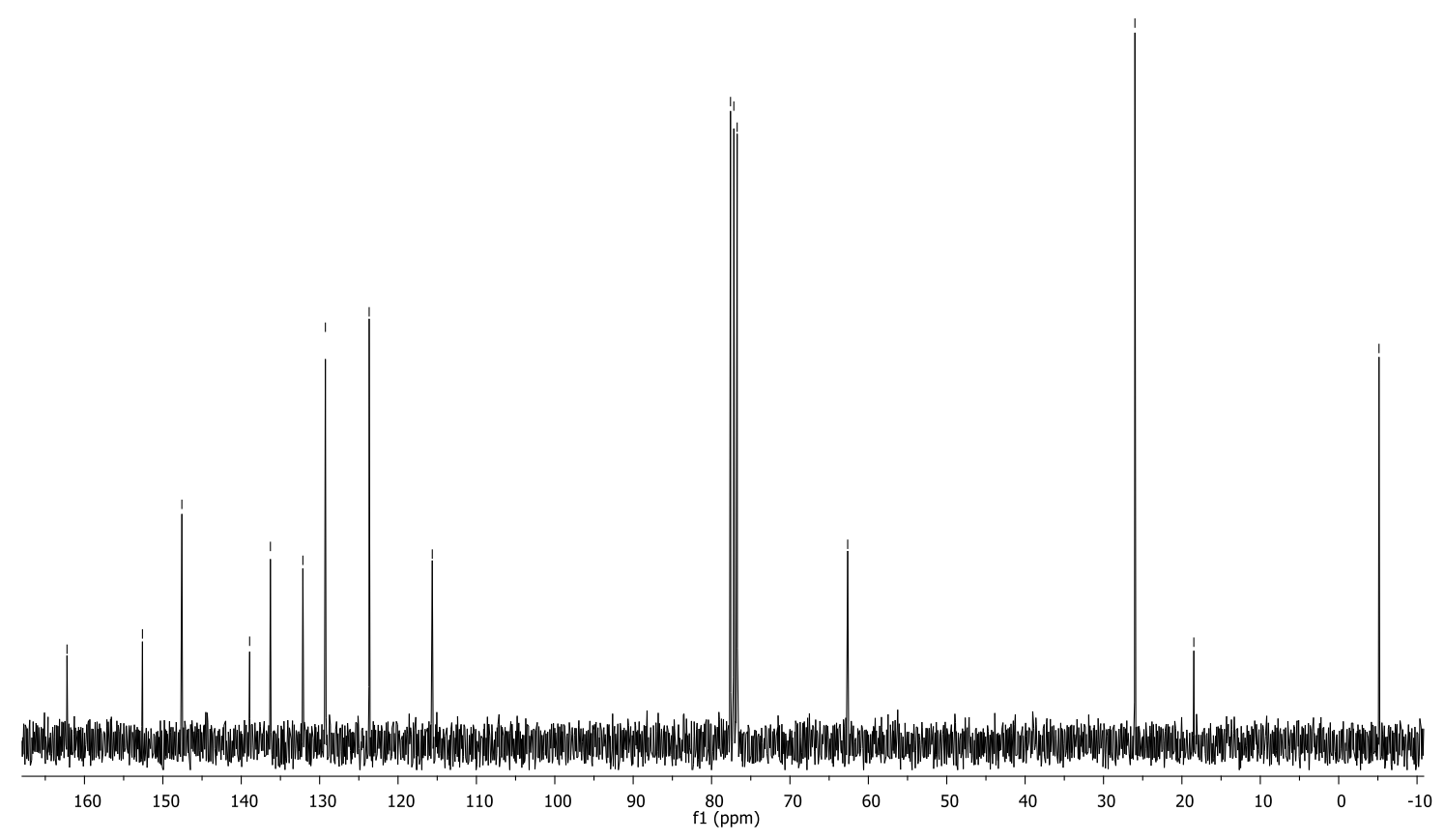


S17

(E)-(6-(phenyldiazenyl)pyridin-3-yl)methanol (5d)

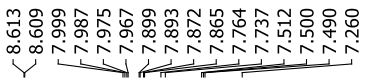

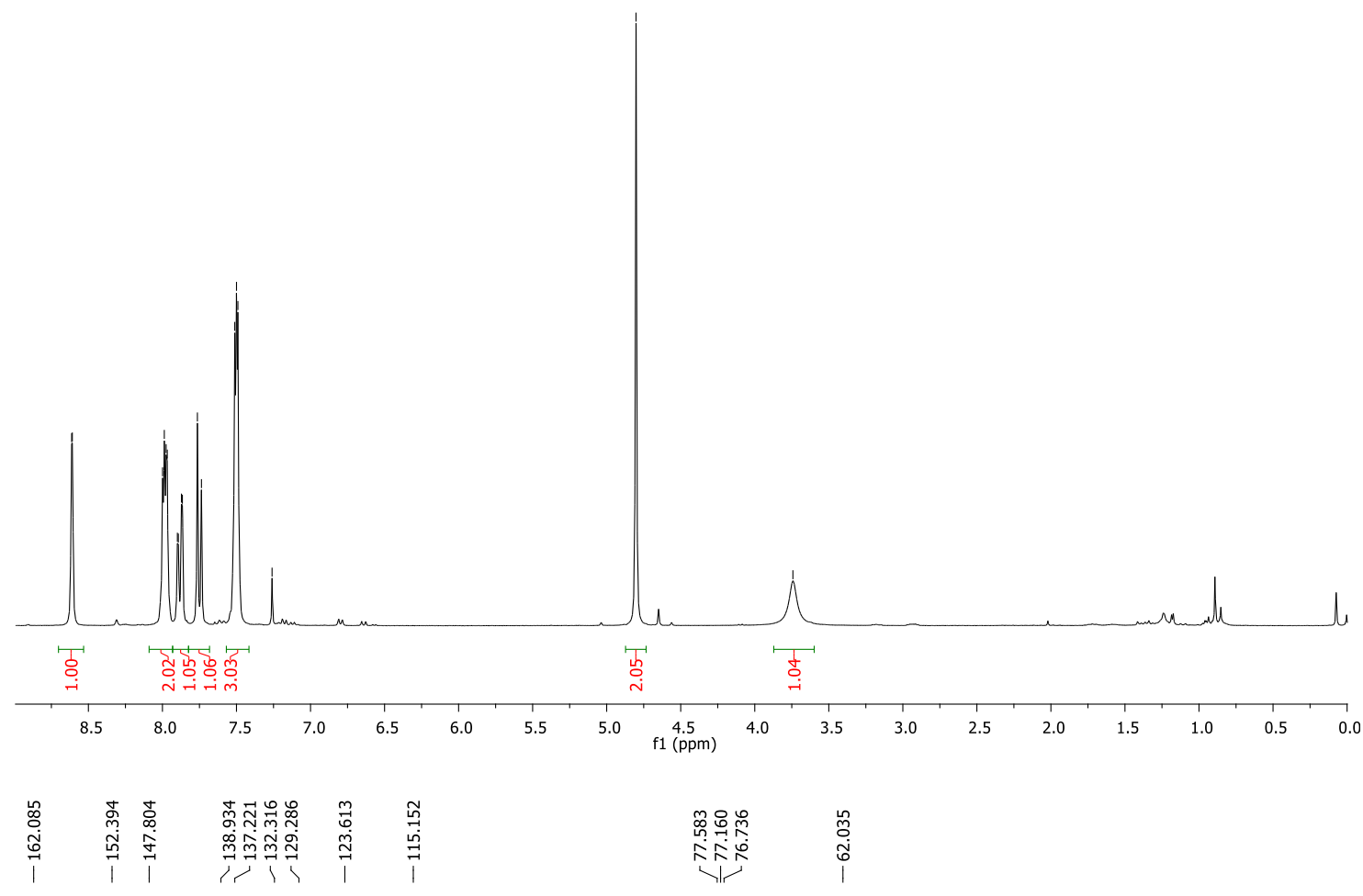

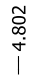

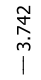

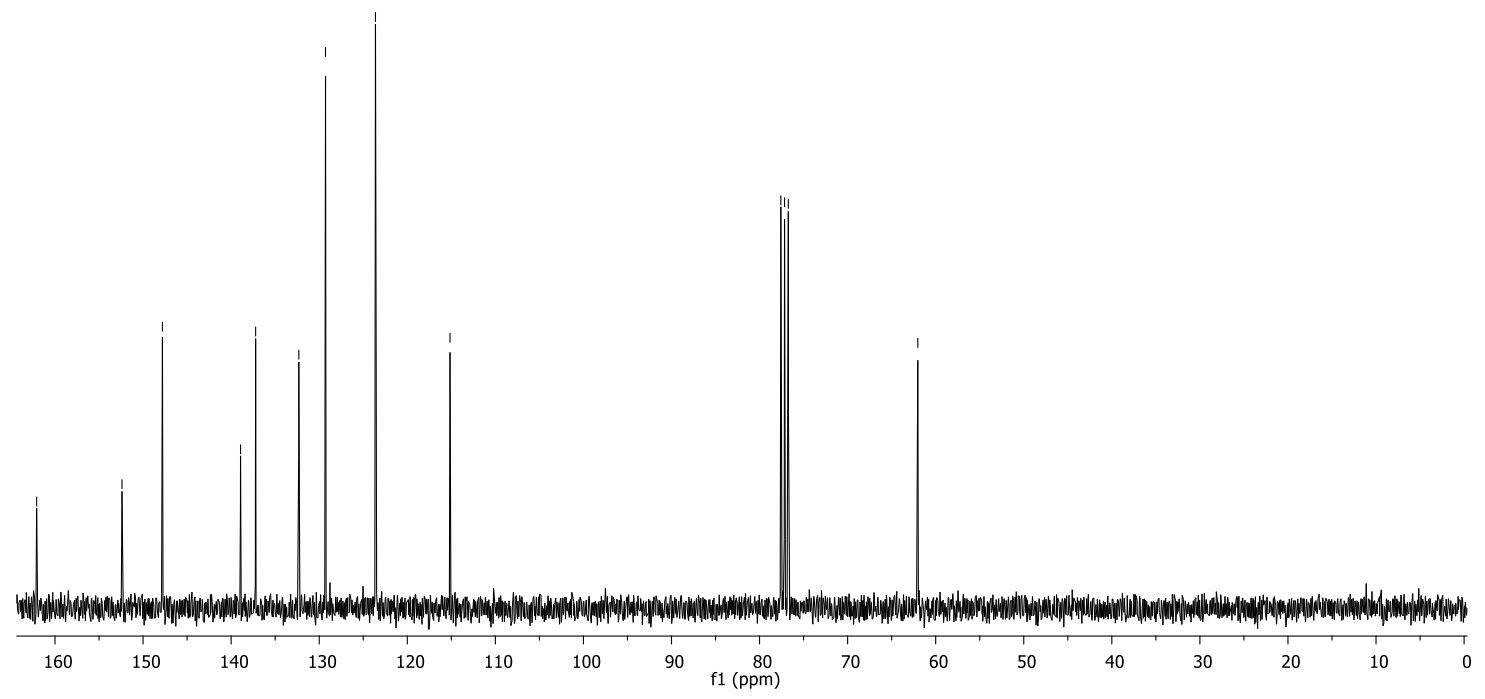


(E)-1-phenyl-2-(p-tolyl)diazene (4e)

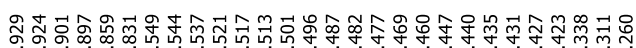

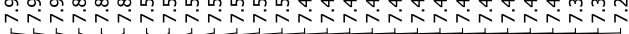

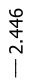
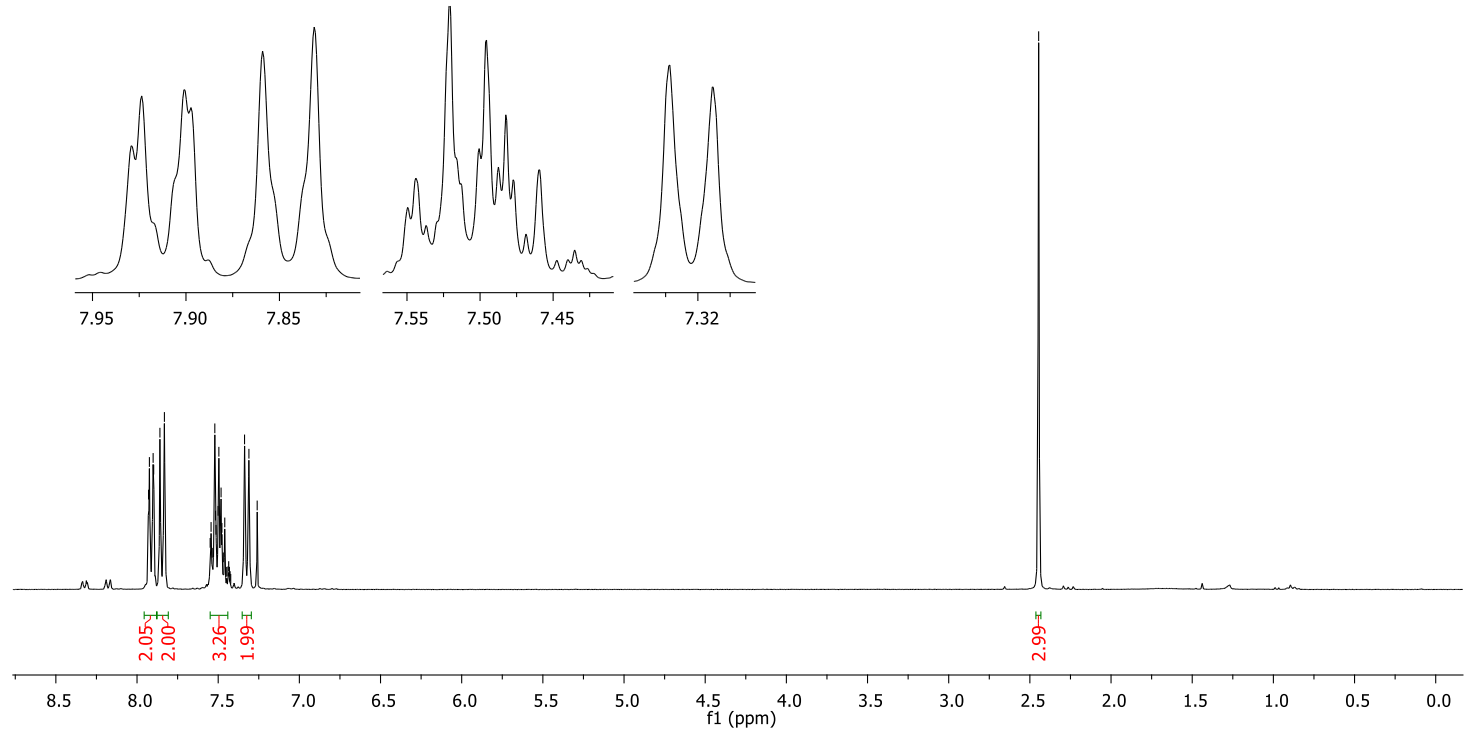

\begin{tabular}{|c|c|c|}
\hline 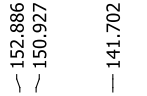 & 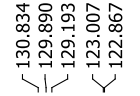 & 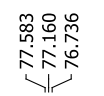 \\
\hline
\end{tabular}

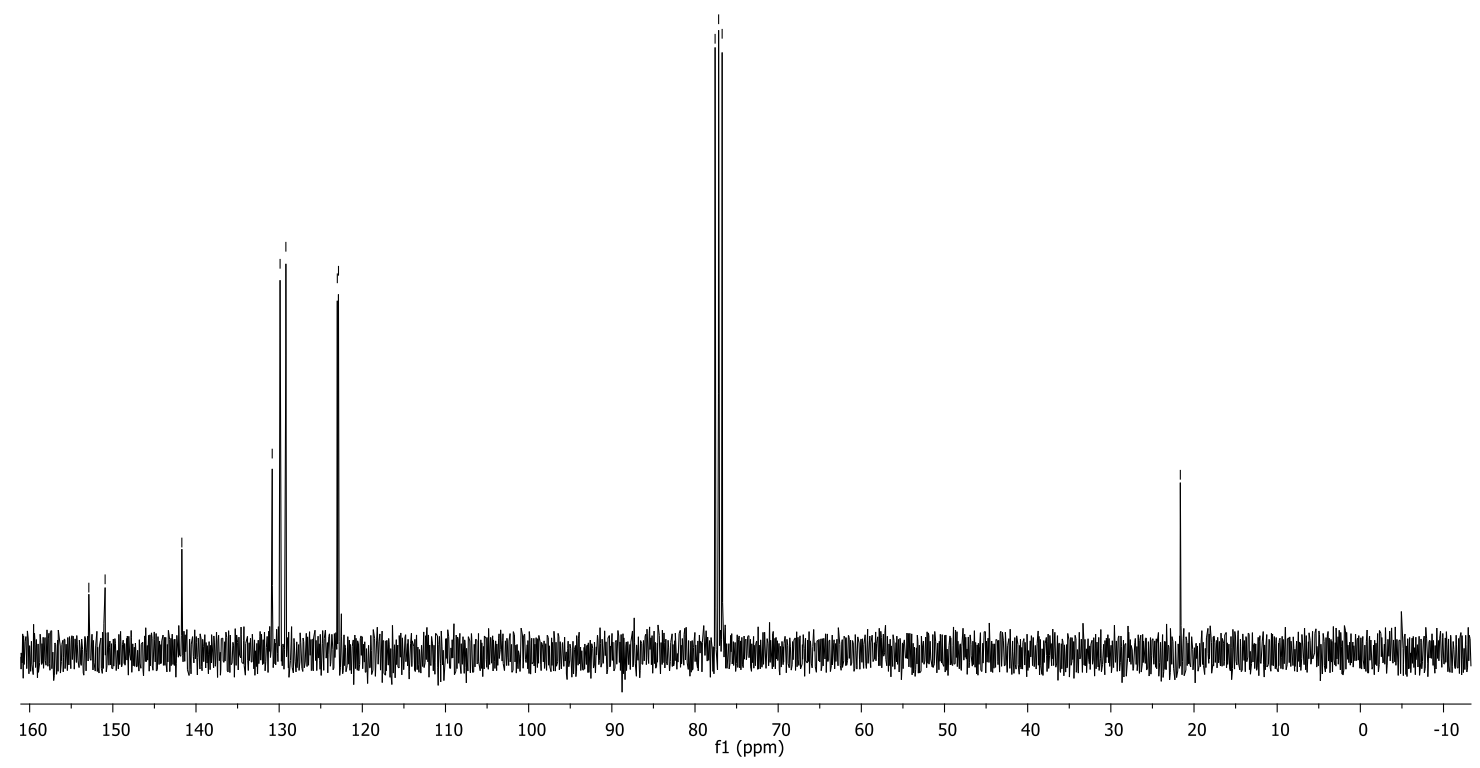


S19

(E)-1-(4-(bromomethyl)phenyl)-2-phenyldiazene (5e)

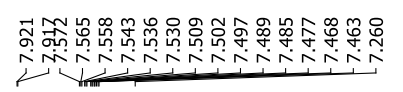

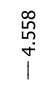
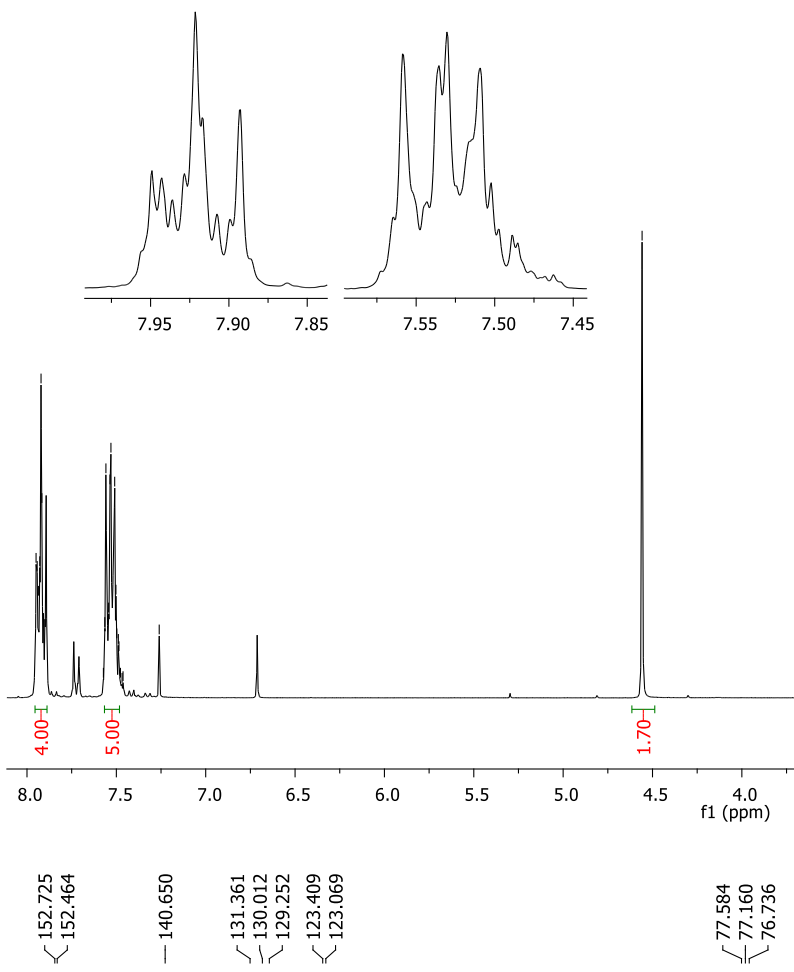

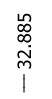

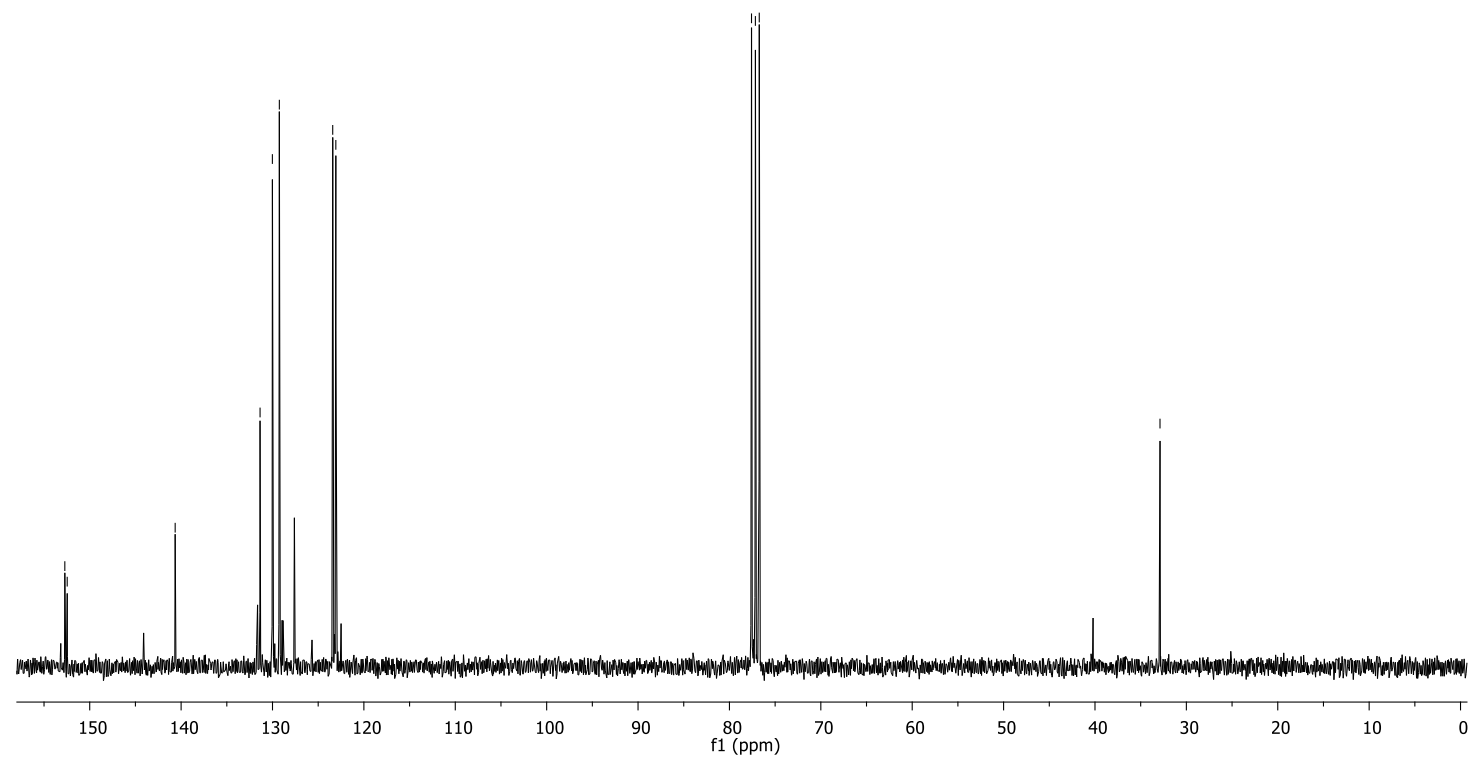


1-(4-phenylcyclohexyl)piperazine, double hydrochloride salt (8)

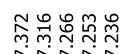

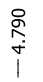

लिîn

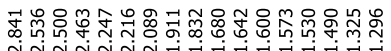

논

f.

1 1) 人1।

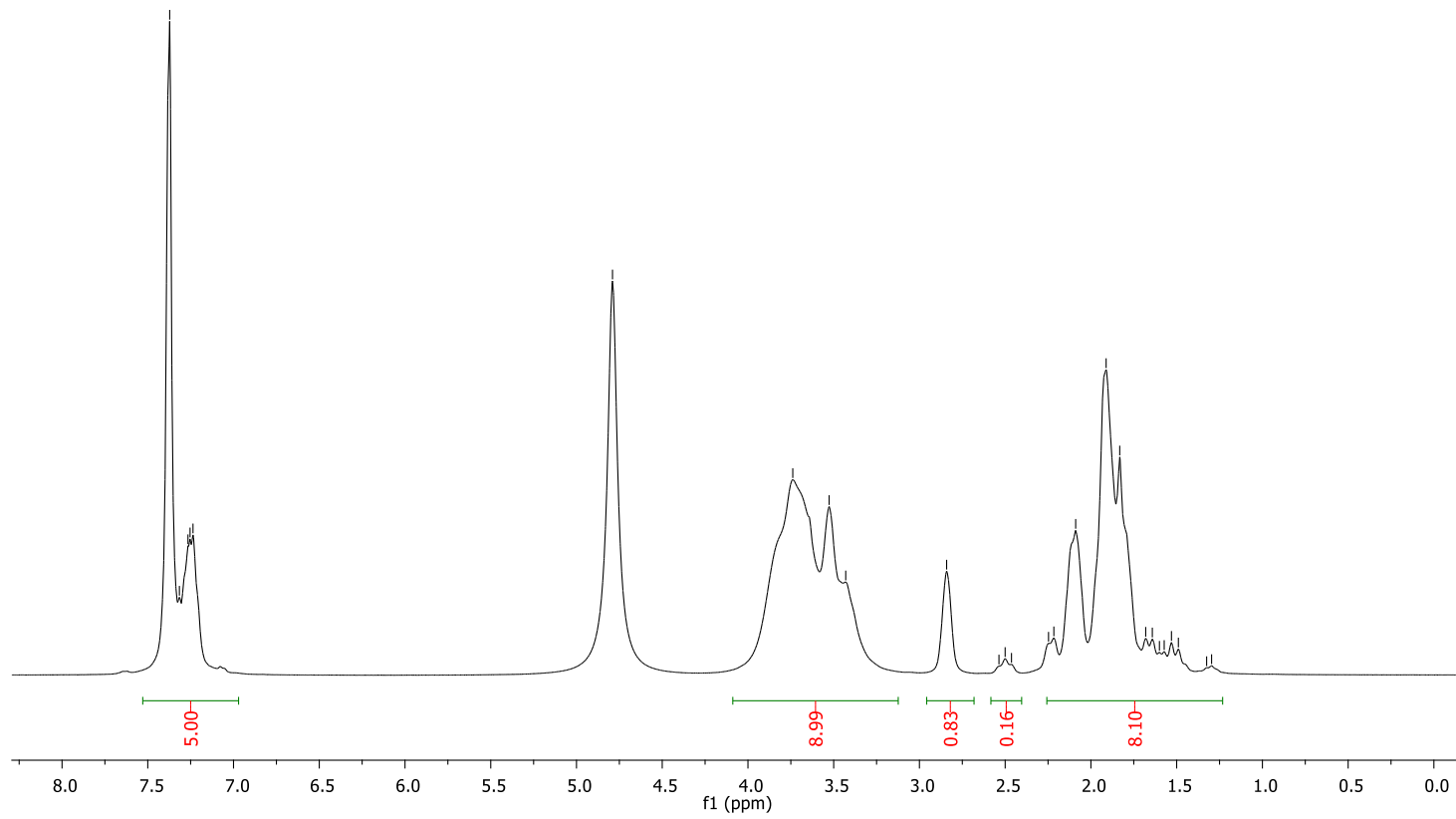

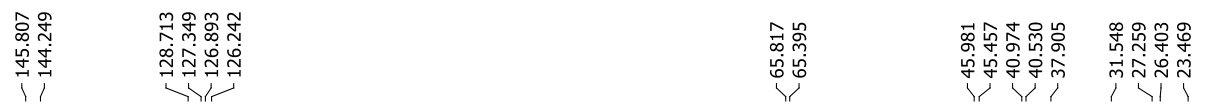

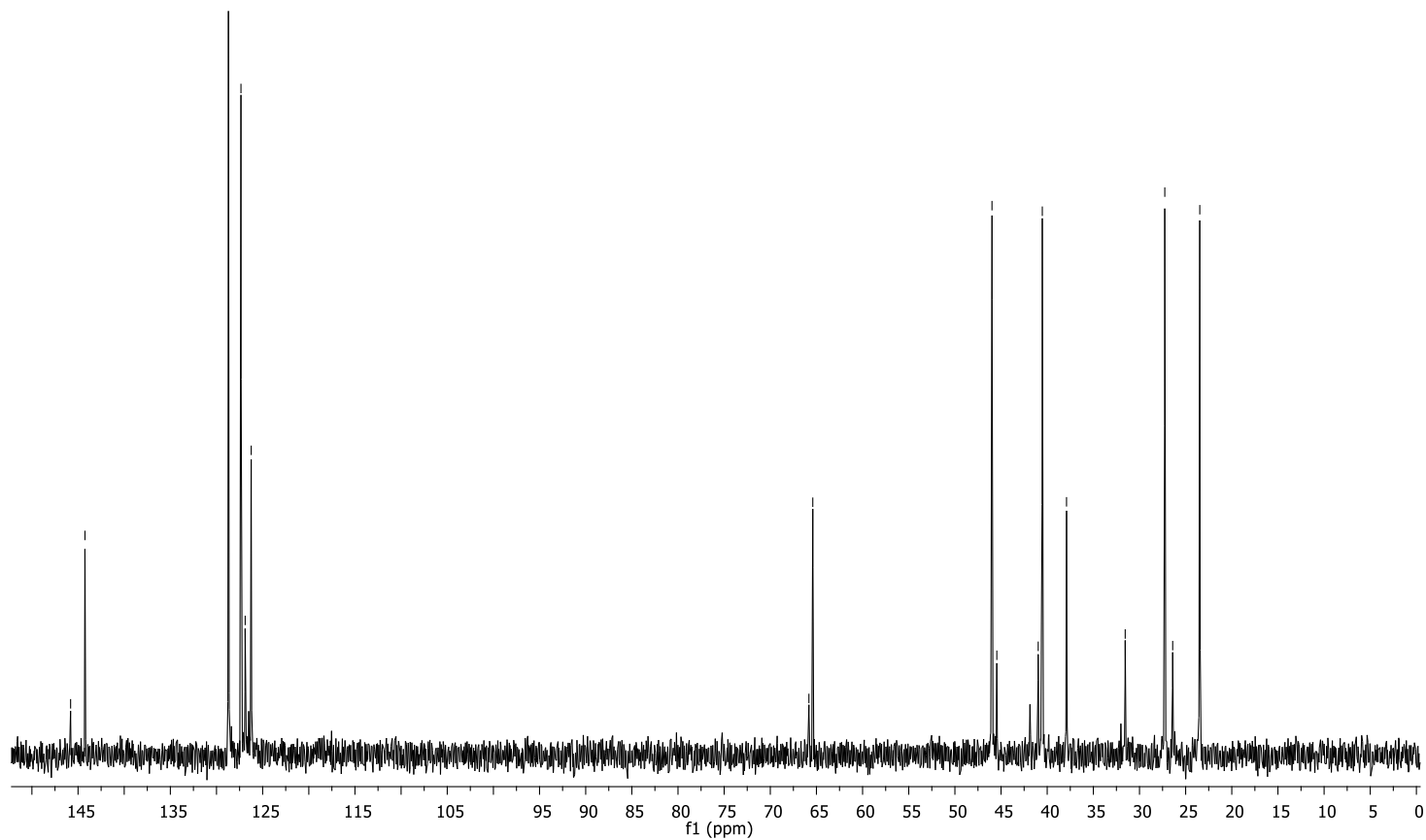




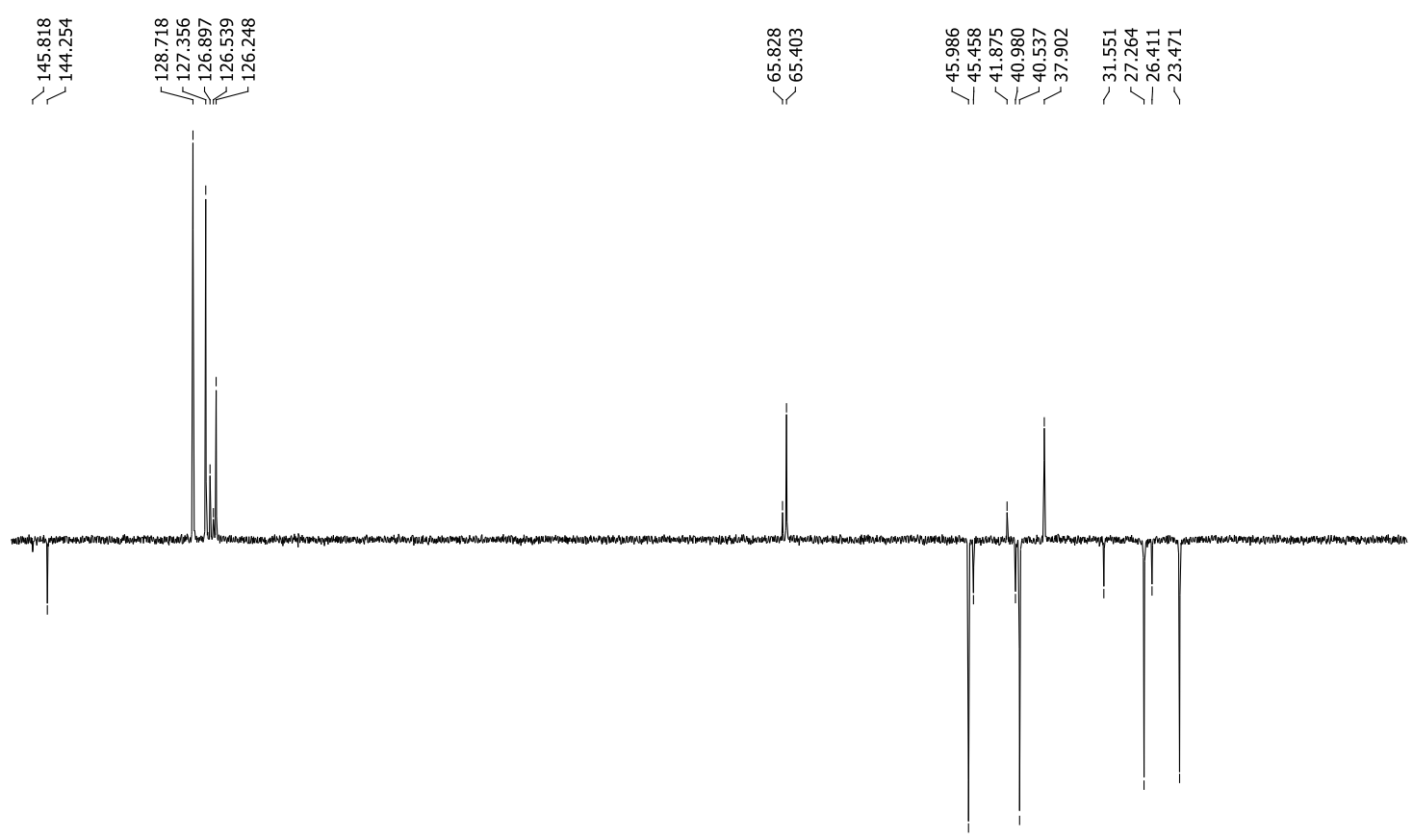

$\begin{array}{llllllllllllllllllllllllllllllllllll}145 & 140 & 135 & 130 & 125 & 120 & 115 & 110 & 105 & 100 & 95 & 90 & 85 & 80 & \begin{array}{c}75 \\ \mathrm{f}(\mathrm{ppm})\end{array} & 65 & 60 & 55 & 50 & 45 & 40 & 35 & 30 & 25 & 20 & 15 & 10 & 5 & 0\end{array}$

1-((1S,4S)-4-phenylcyclohexyl)-4-(6-((E)-phenyldiazenyl)pyridin-3-yl)piperazine, double hydrochloride salt (9a)

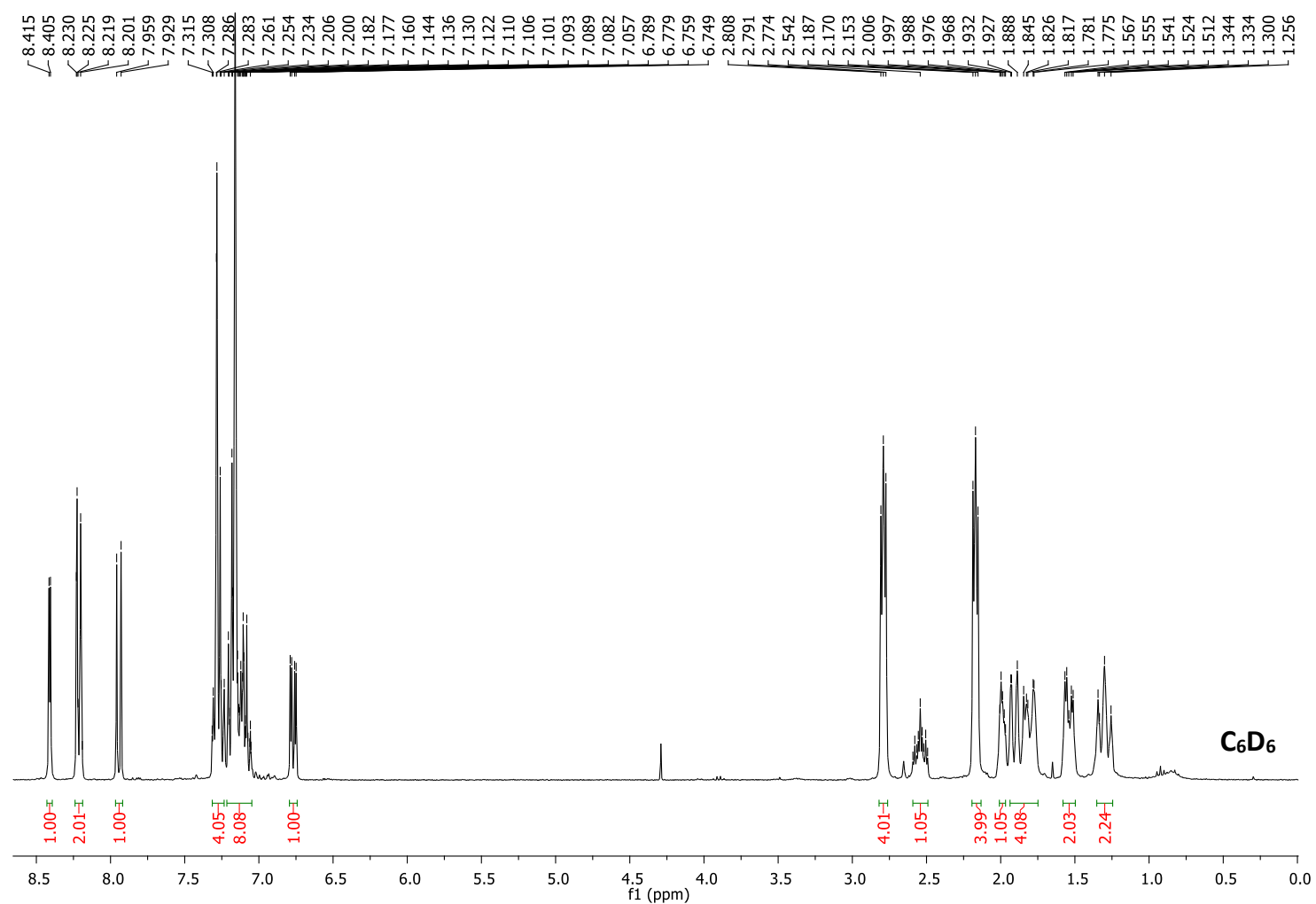




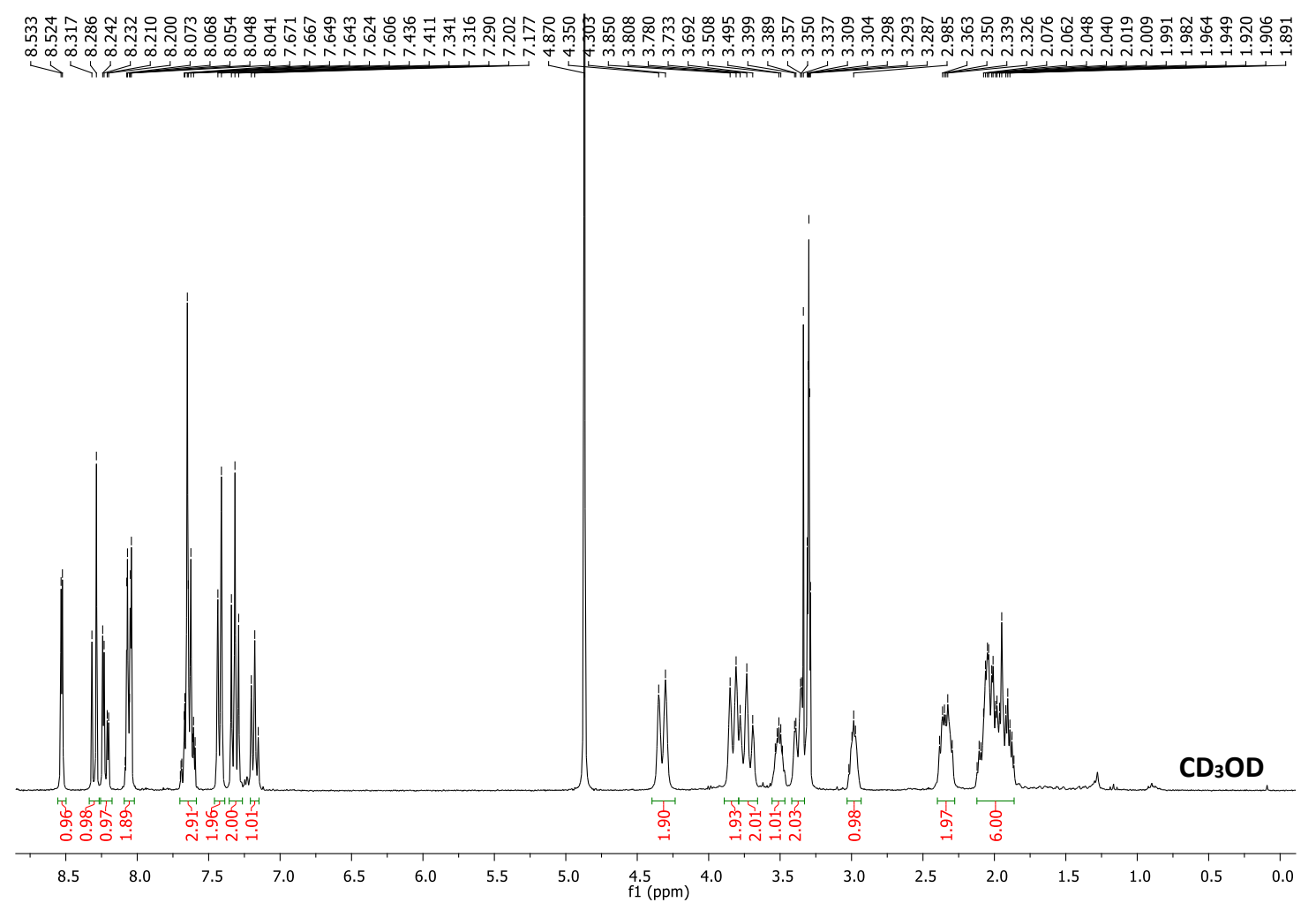

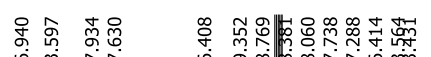

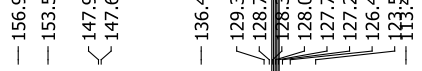

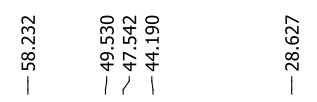

$\mathrm{C}_{6} \mathrm{D}_{6}$

1.

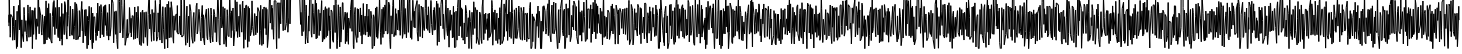

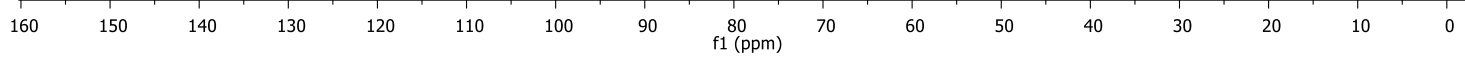




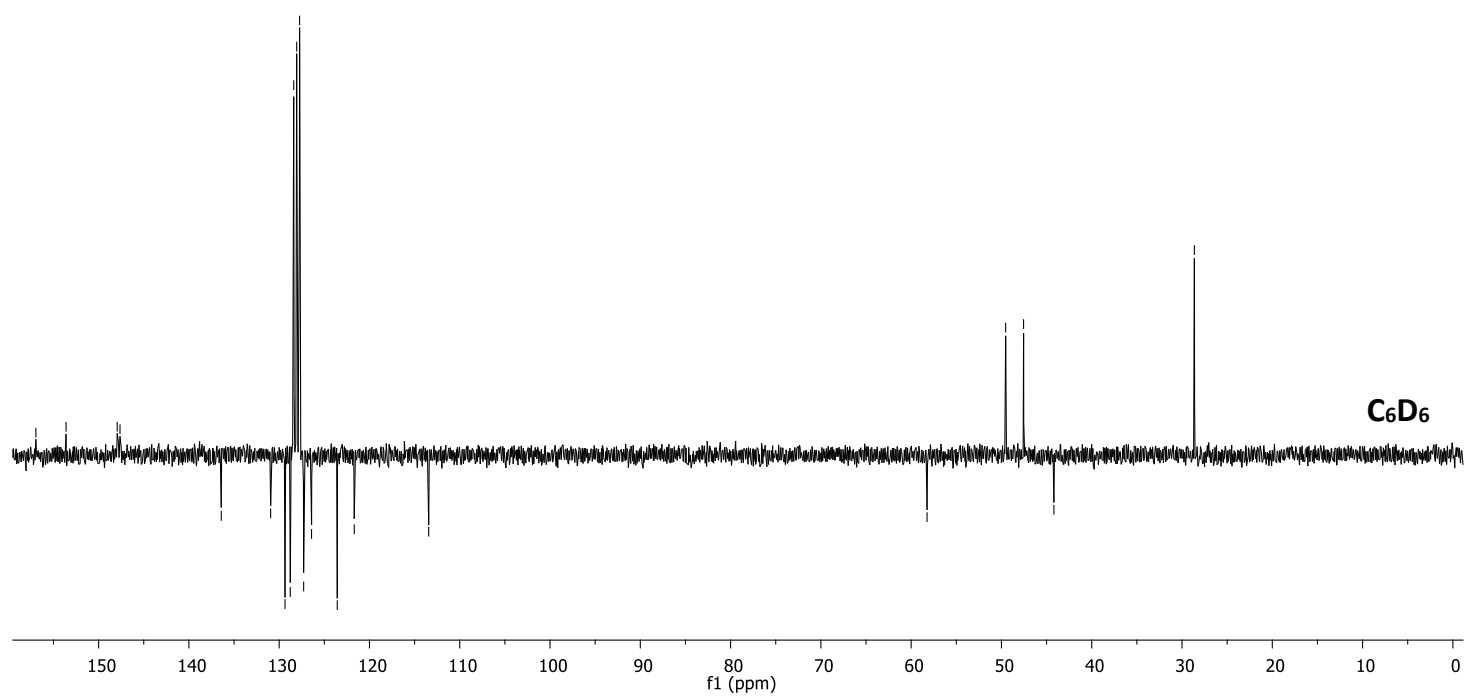

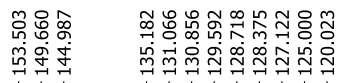

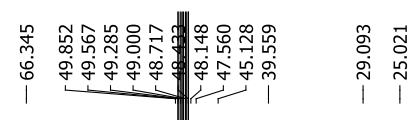

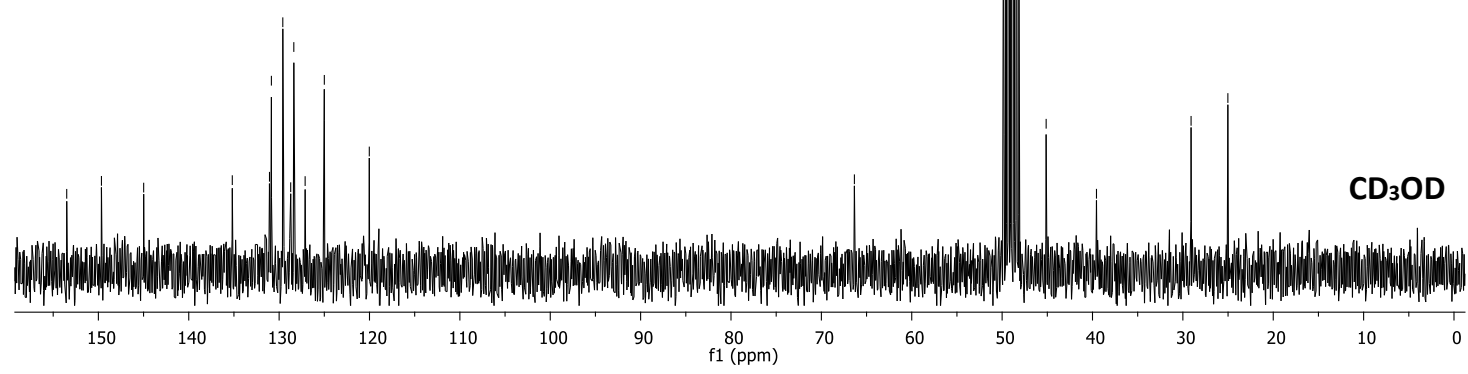




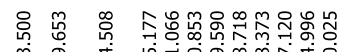

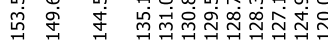

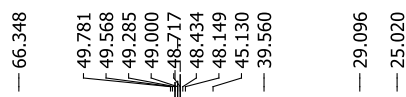

$\mathrm{CD}_{3} \mathrm{OD}$

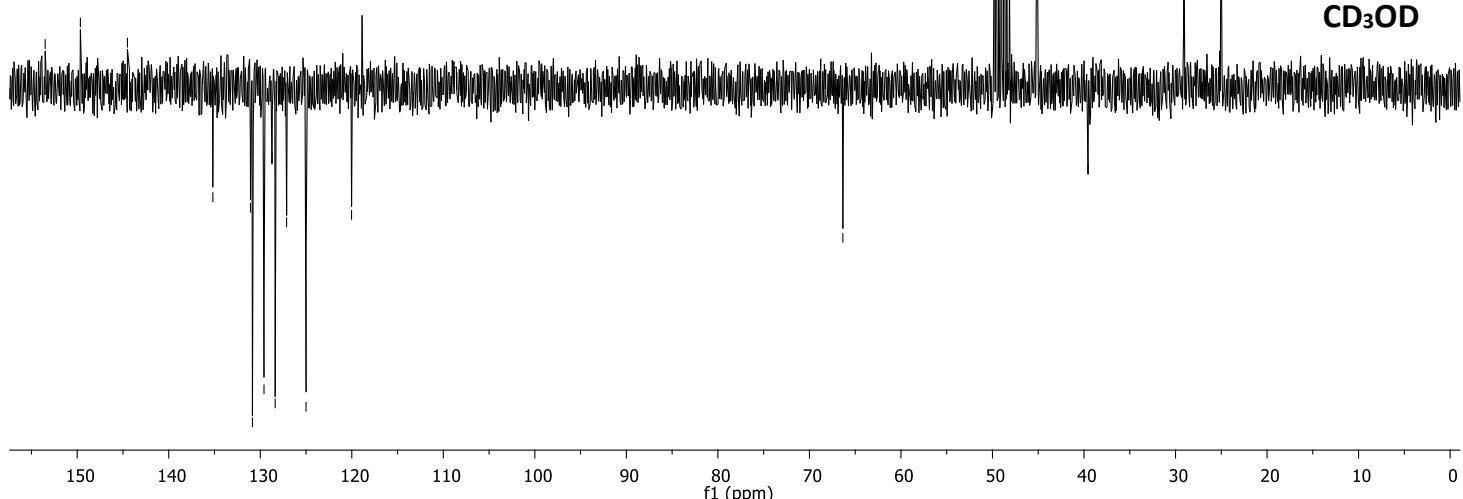

1-((1S,4S)-4-phenylcyclohexyl)-4-(4-((E)-phenyldiazenyl)phenyl)piperazine, hydrochloride salt $(9 b)$
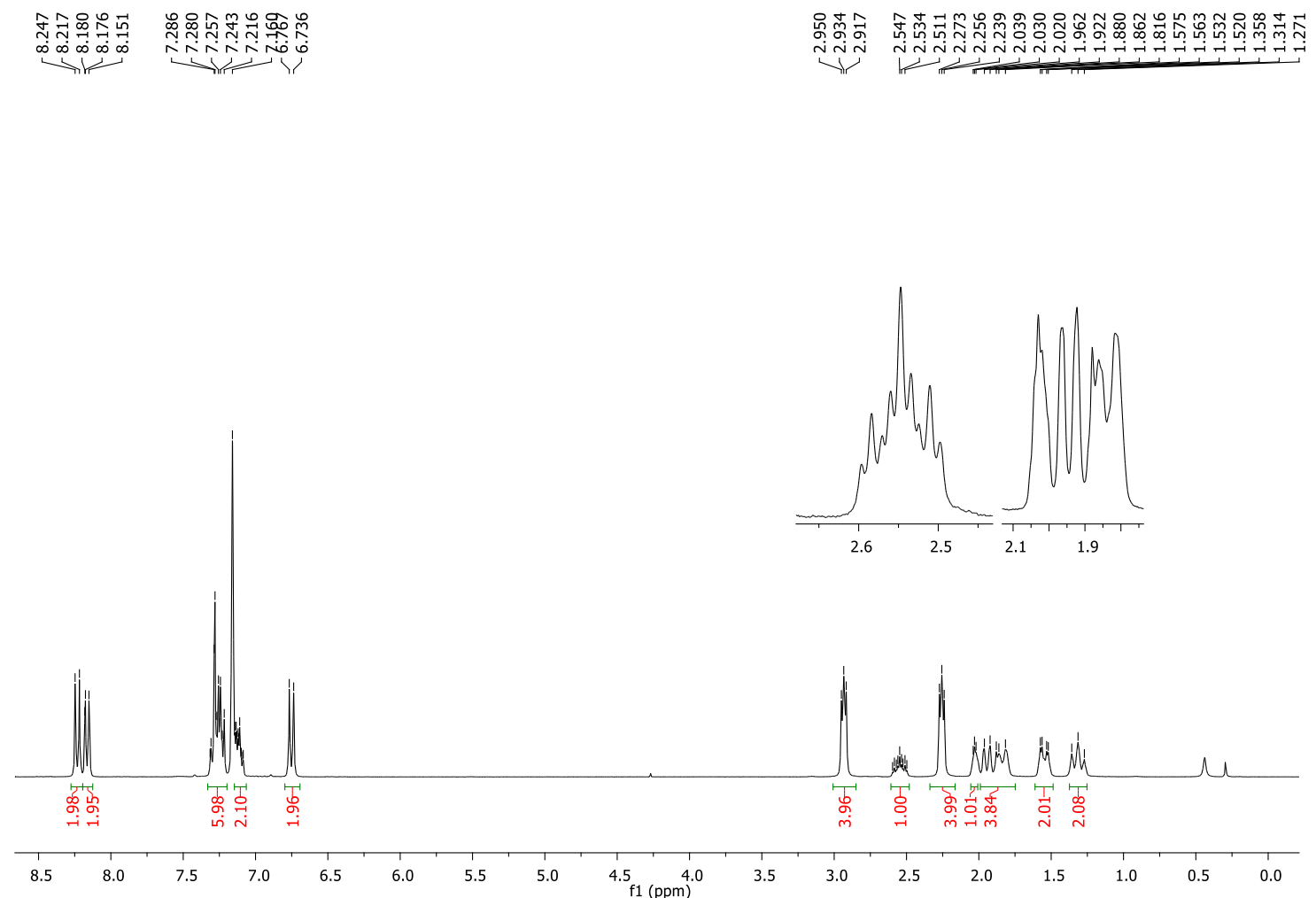


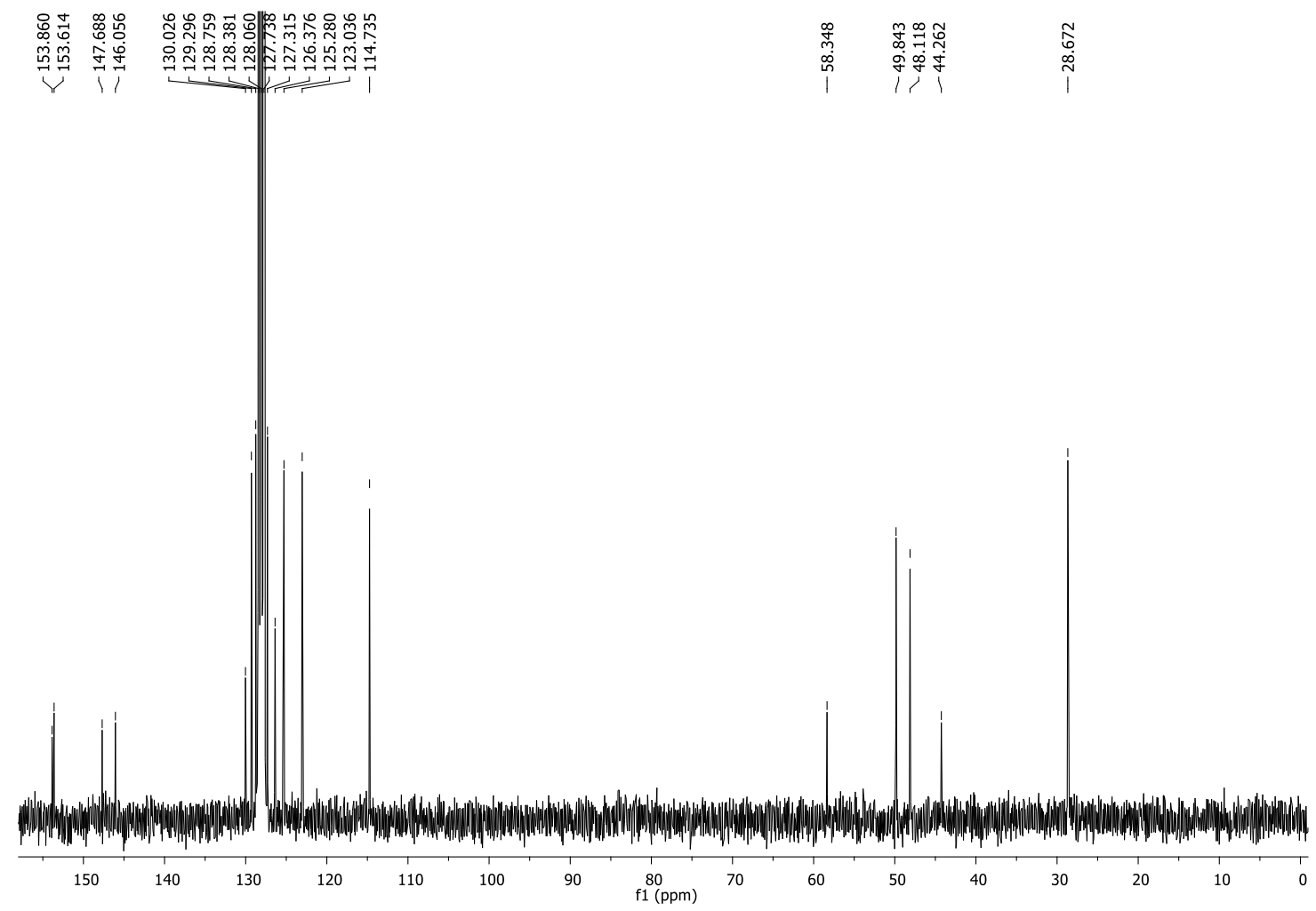

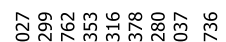

苞
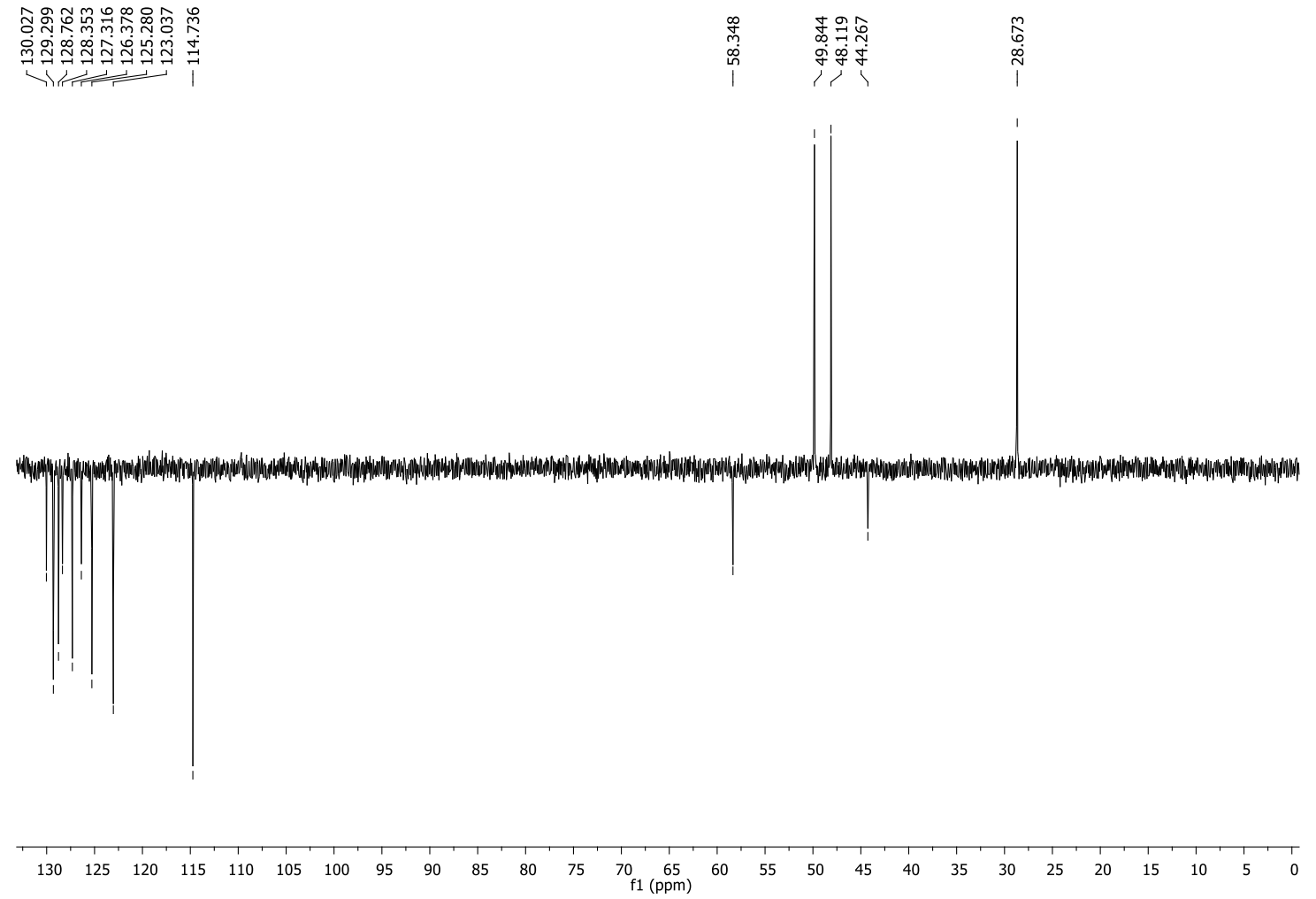
S26

1-((1S,4S)-4-phenylcyclohexyl)-4-(4-((E)-pyridin-3-yldiazenyl)phenyl)piperazine, double hydrochloride salt $(9 \mathrm{c})$
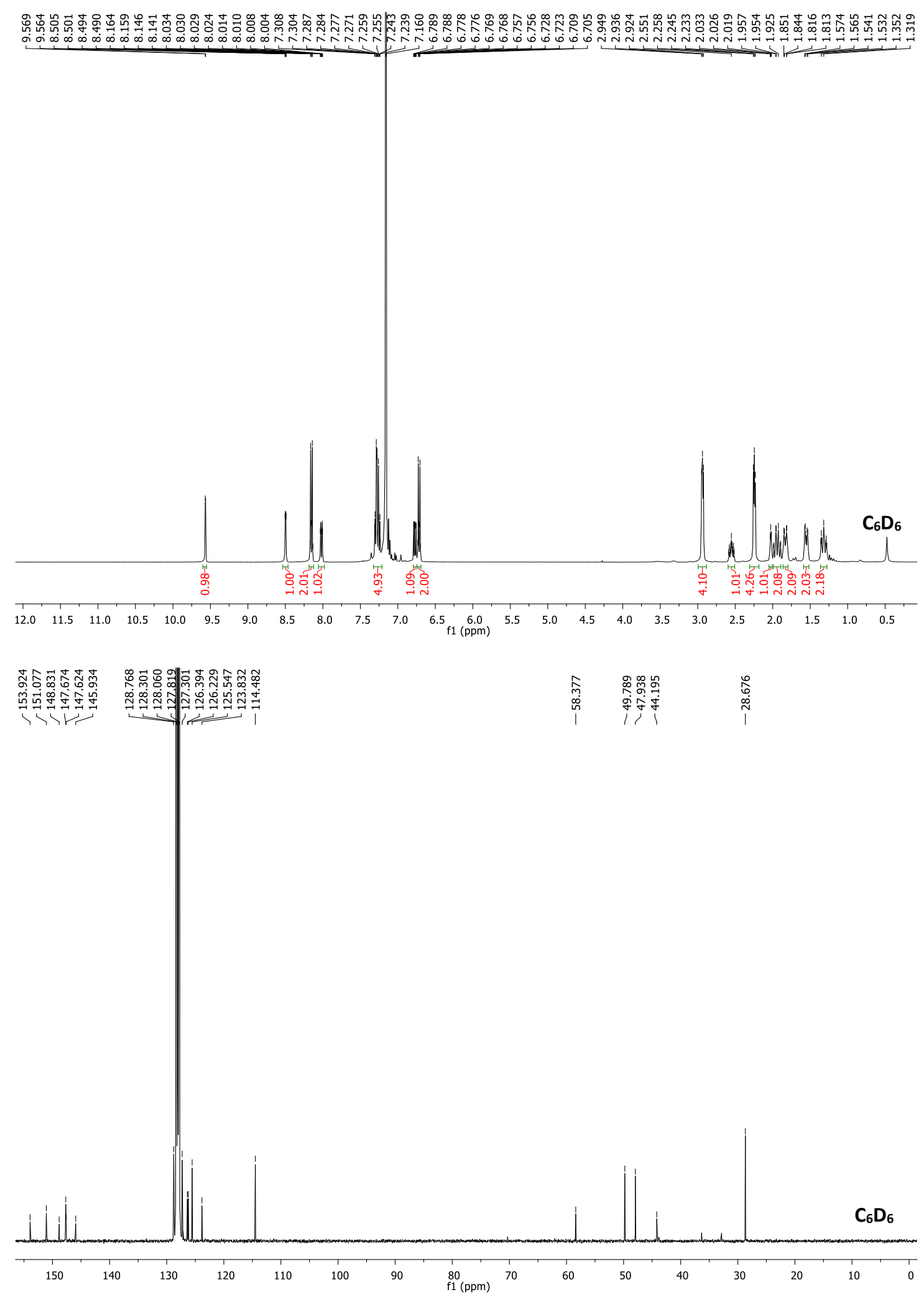


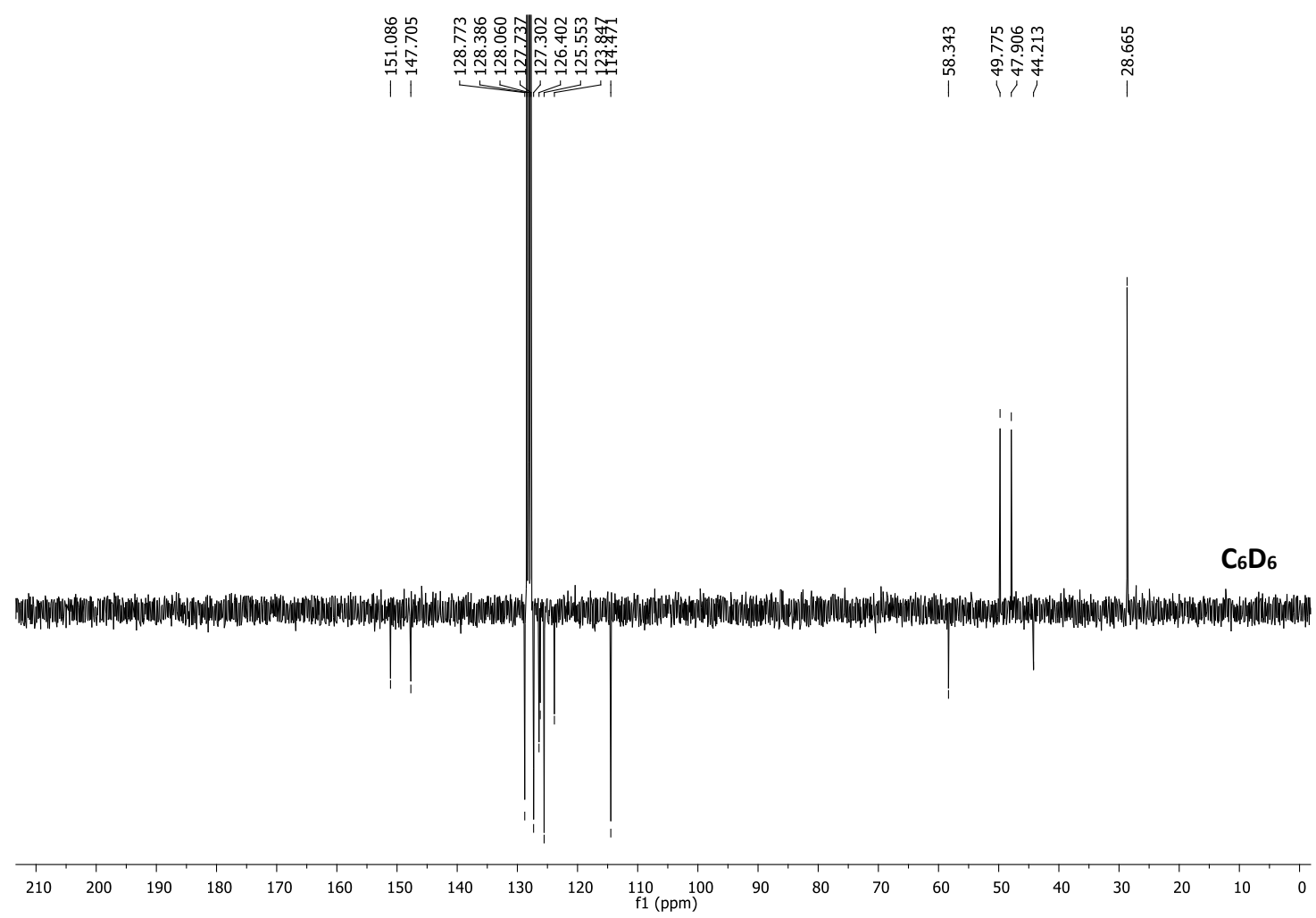

1-((1S,4S)-4-phenylcyclohexyl)-4-((6-((E)-phenyldiazenyl)pyridin-3-

yl)methyl)piperazine, double hydrochloride salt (9d)

ن

l.

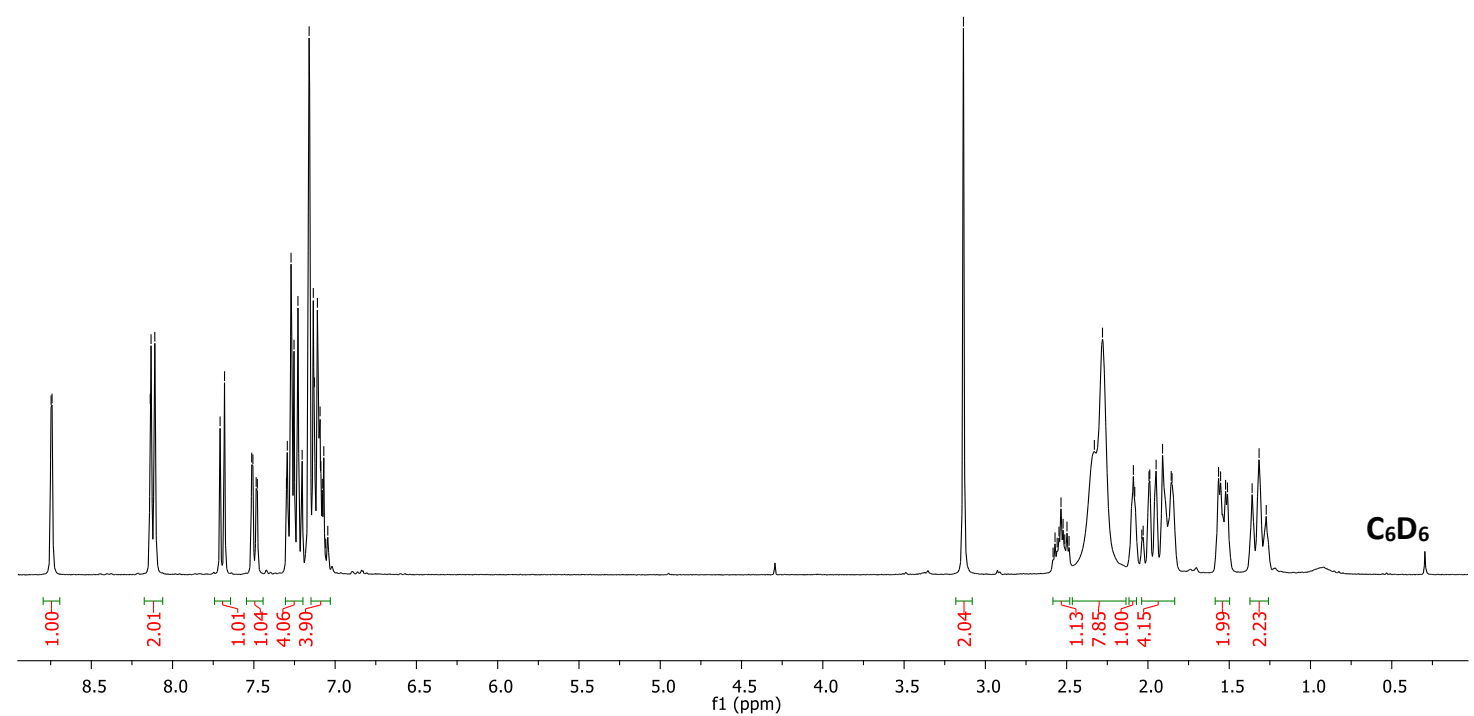




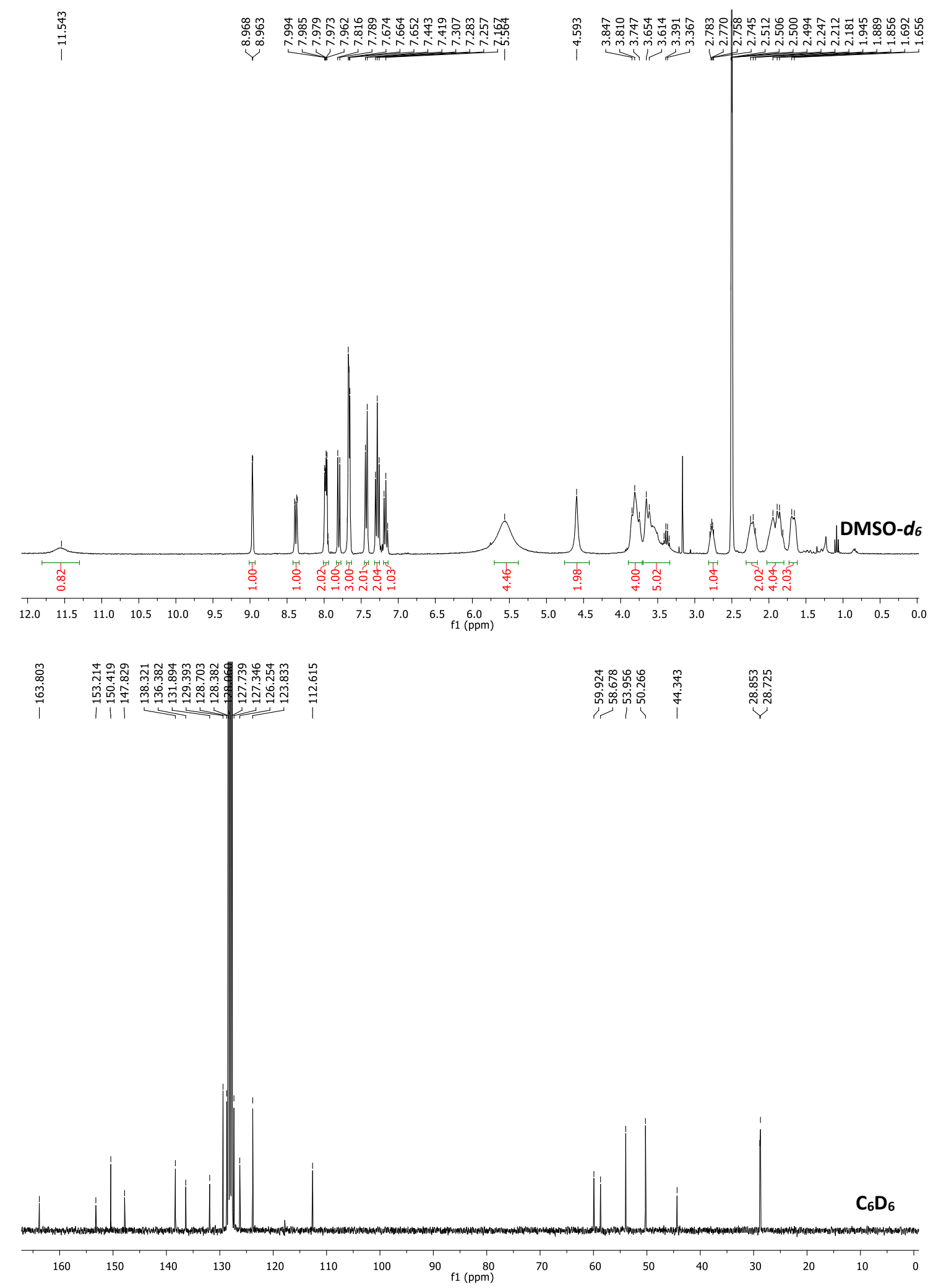




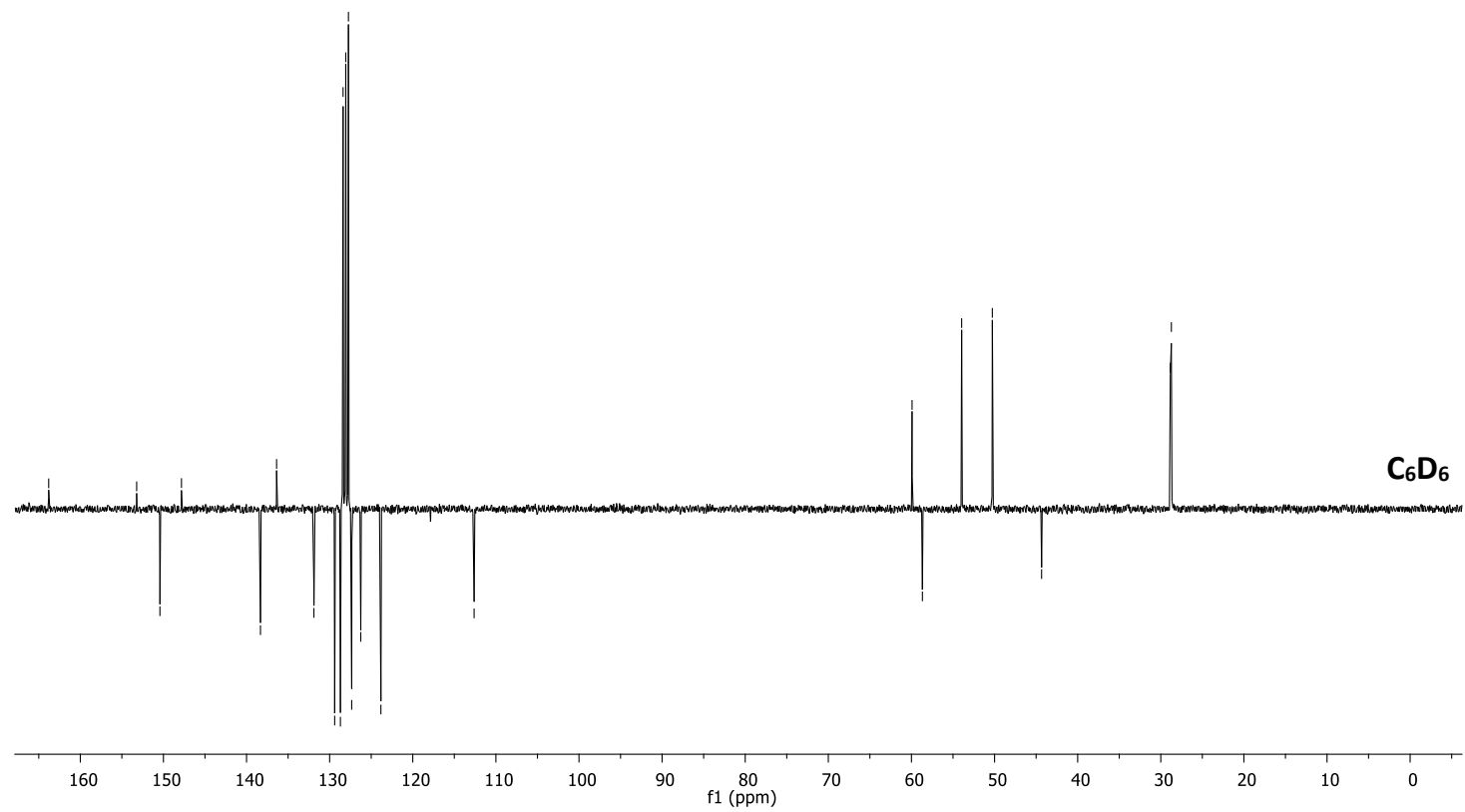

1-((1S,4S)-4-phenylcyclohexyl)-4-(4-((E)-phenyldiazenyl)benzyl)piperazine, double hydrochloride salt (9e)

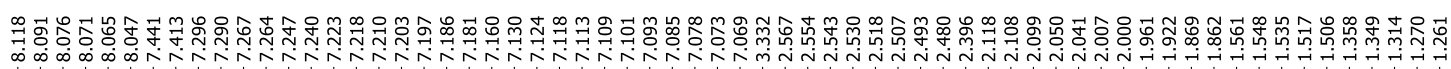

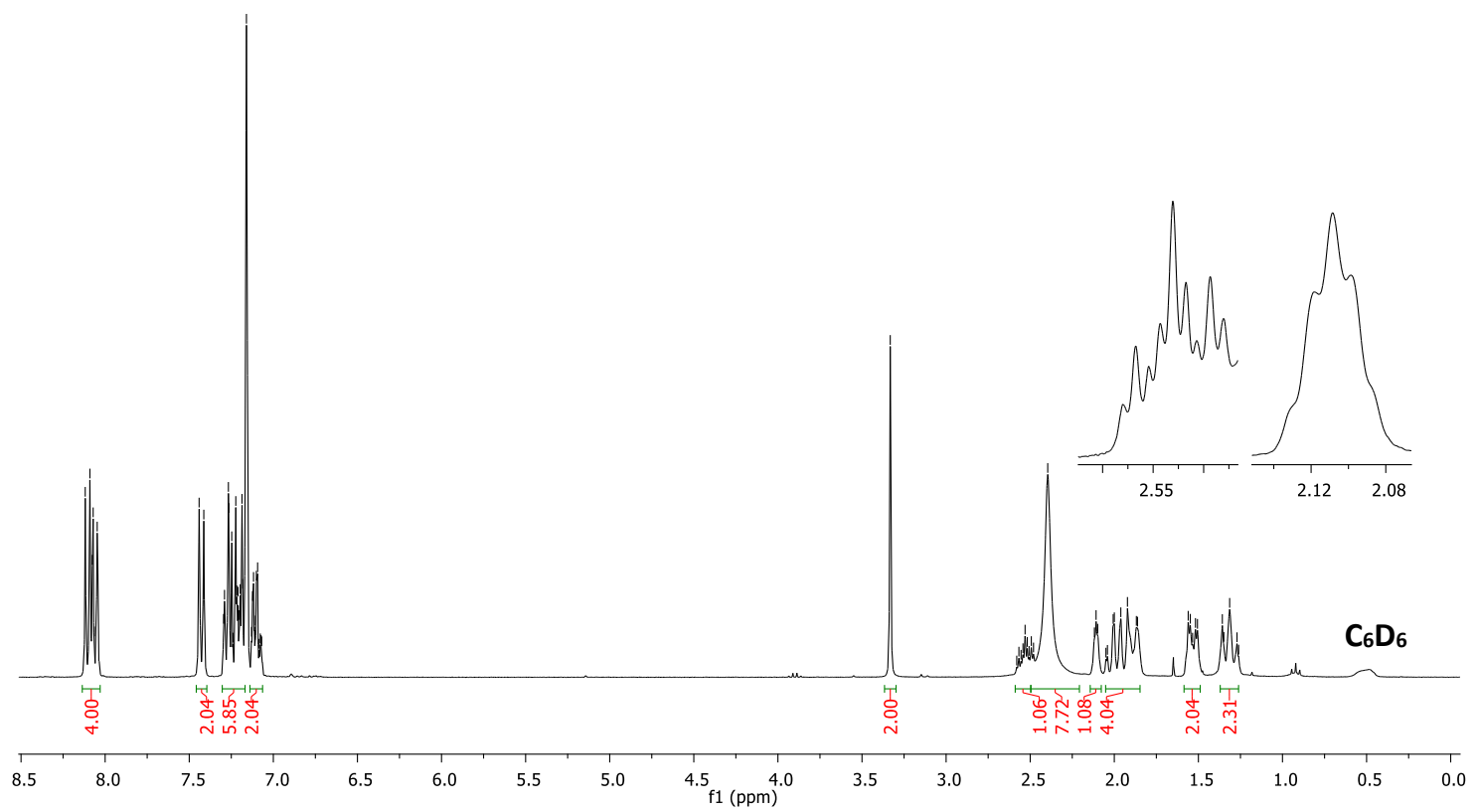




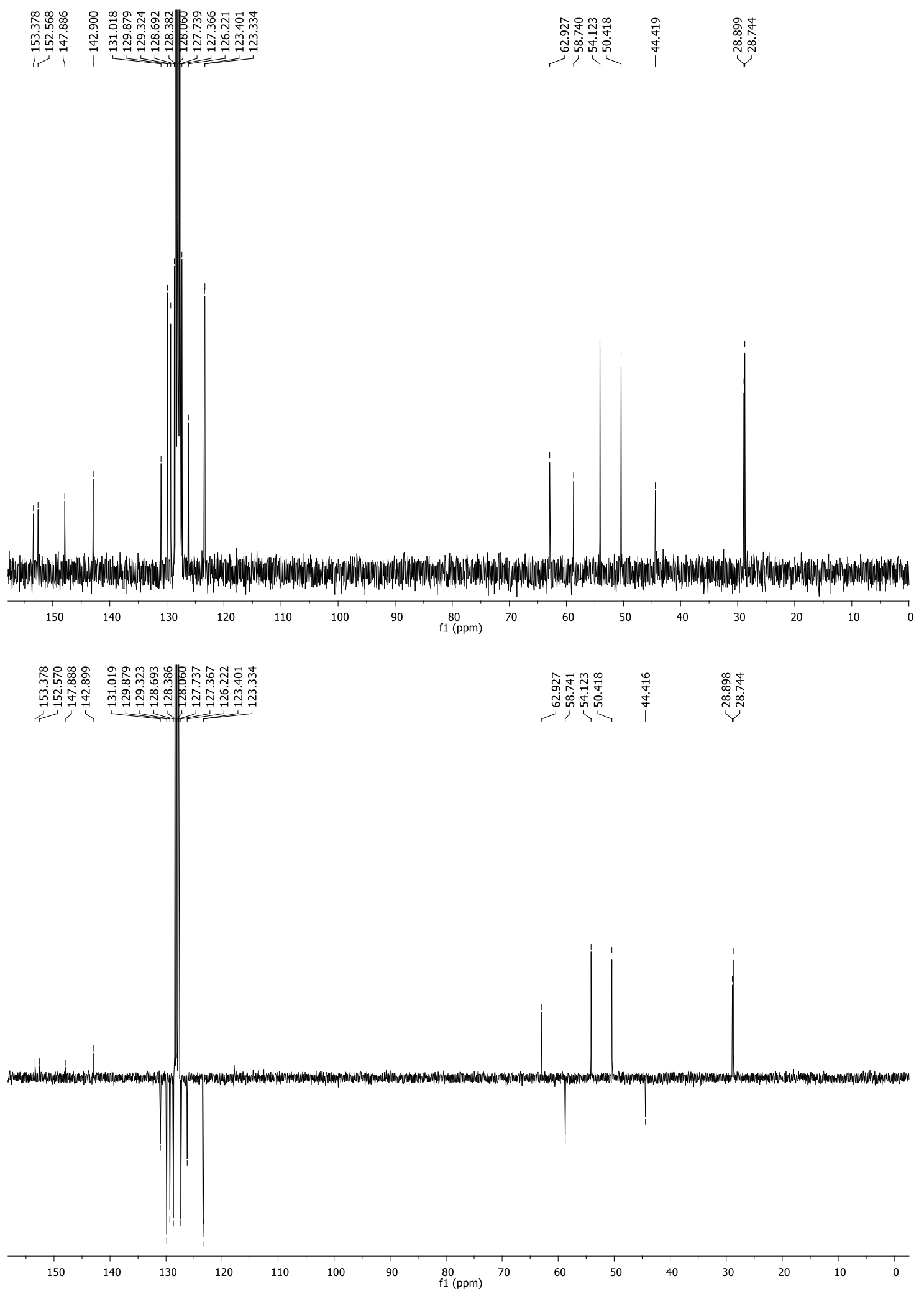




\section{X-Ray crystal structure report}

$$
\text { cl1 (8) }
$$

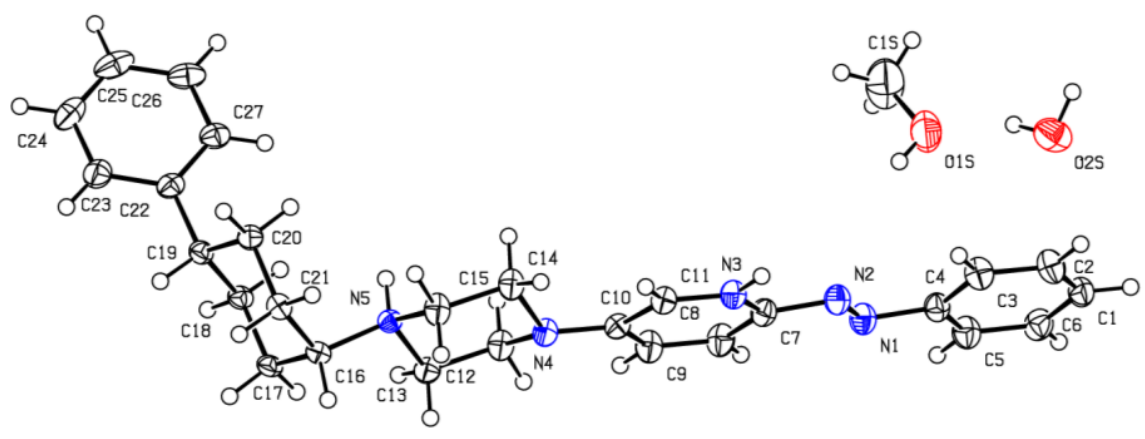

9a

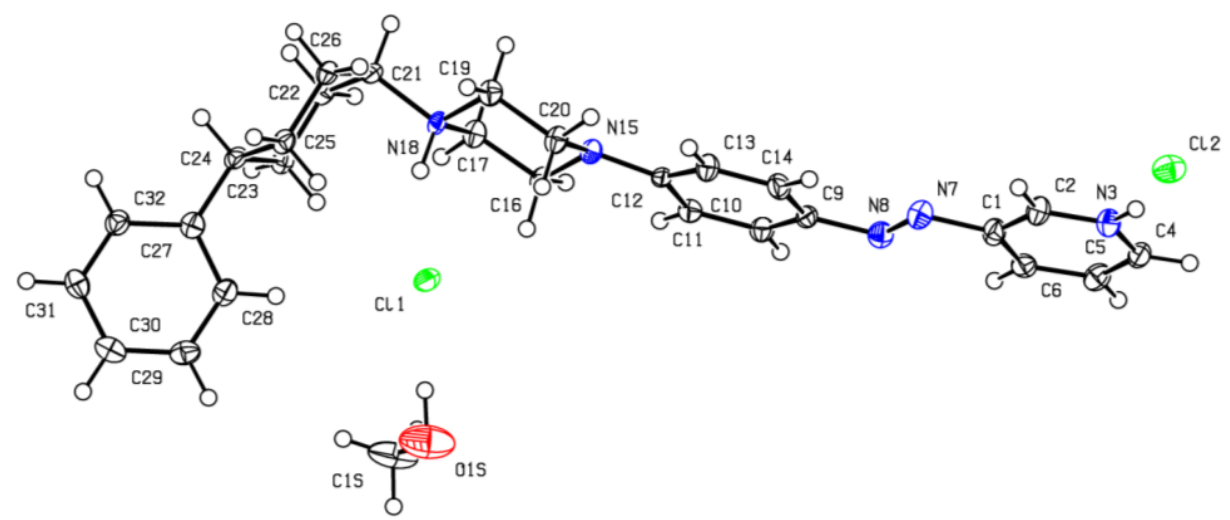

$9 \mathrm{c}$

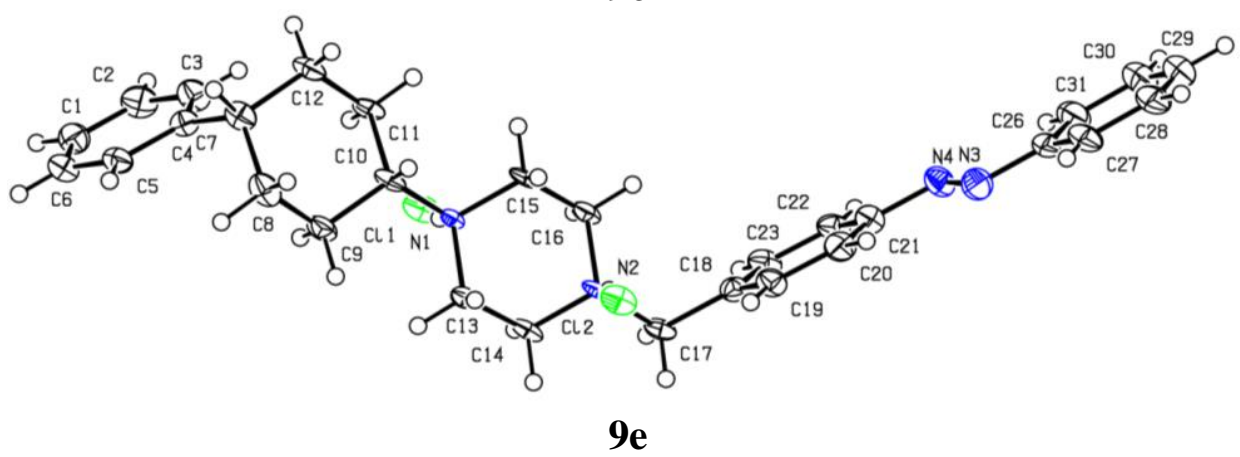

Figure S2. X-ray crystal structures of 9a (CCDC 1906657), 9c (CCDC 1906654) and 9e (CCDC 1906656) shown as ORTEP with ellipsoids drawn at the 50\% probability level. Hydrogen atoms (white spheres, arbitrary radius) were located in the difference Fourier map and refined freely. The analysis reveal that for all compounds, the stable $E$ configuration of the diazobenzene were present. The cyclohexyl ring adopts a chair conformation (cis-diastereomer). CCDC codes contains the supplementary crystallographic data for this paper. The data can be obtained free of charge from The Cambridge Crystallographic Data Centre via www.ccdc.cam.ac.uk/structures. 


\section{Photochemical properties of 9a-e.}

The photoisomerization was determined using the procedures described by Lutz et al $(2018)^{1}$ and Schehr et al (2019) ${ }^{2}$ with modifications. Briefly, the UV-vis spectra (Tecan Infinite ${ }^{\circledR}$ M1000 PRO) of $500 \mu \mathrm{M}$ DMSO solutions of each individual compound maintained in the dark was recorded. Then, the samples were irradiated under $365 \mathrm{~nm}$ (5 min) and the UV-vis spectra were recorded immediately. Finally, the previous procedure was performed again with an additional irradiation at $470 \mathrm{~nm}(5 \mathrm{~min})$ and the UV-vis spectra was recorded immediately (Figure S3). In parallel, the stock solutions of selected compounds were diluted to $0.9 \mathrm{mM}$ and were injected in the UPLC-MS before and after irradiation at $365 \mathrm{~nm}$ for $5 \mathrm{~min}$ in order to calculate the ratio between $E$ - and $Z$-isomers (assigned as $\alpha_{(E) /(Z))}$.

In order to analyze the thermal isomerization $\left(\mathrm{T}_{1 / 2}\right)$ of compounds $9 \mathbf{a}, 9 \mathbf{d}$ and $9 \mathbf{e}$, their $500 \mu \mathrm{M}$ solutions (DMSO) were stored in the dark for at least $48 \mathrm{~h}$. After recording the spectra, the samples were $365 \mathrm{~nm}$ irradiated (5 min) and UV-vis spectra were recorded in defined time intervals. The $\lambda_{\max (\mathrm{E})}$ was plotted in function of time and the equation of onephase association was calculated (GraphPad® Software, v. 5.0, San Diego, CA, US).

For the photostability of 9e, UV-vis spectra of $500 \mu \mathrm{M}$ DMSO was recorded immediately after alternate cycles of irradiation, at $365 \mathrm{~nm}$ and $470 \mathrm{~nm}$ (5 min each), respectively. Then, the absorbance at $327 \mathrm{~nm}$ was plotted as function of the cycle of irradiation.
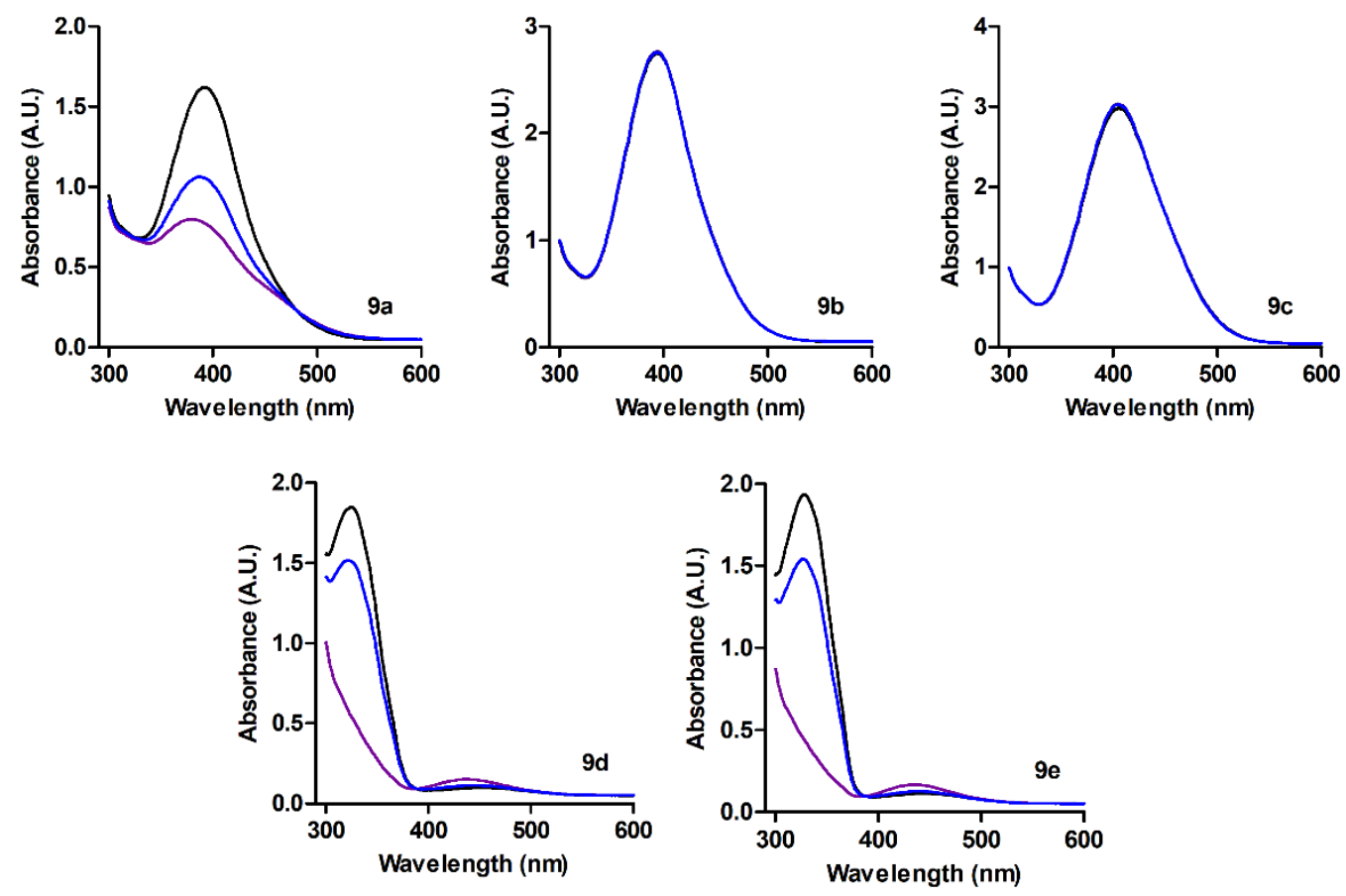
Figure S3. Individual UV-Vis spectra of compounds 9a-e (DMSO, $500 \mu \mathrm{M})$, in the darkadapted (black), UV-adapted (magenta, $365 \mathrm{~nm}$ ), blue-adapted (blue, $470 \mathrm{~nm}$ ) states.

\subsection{UPLC chromatogram}

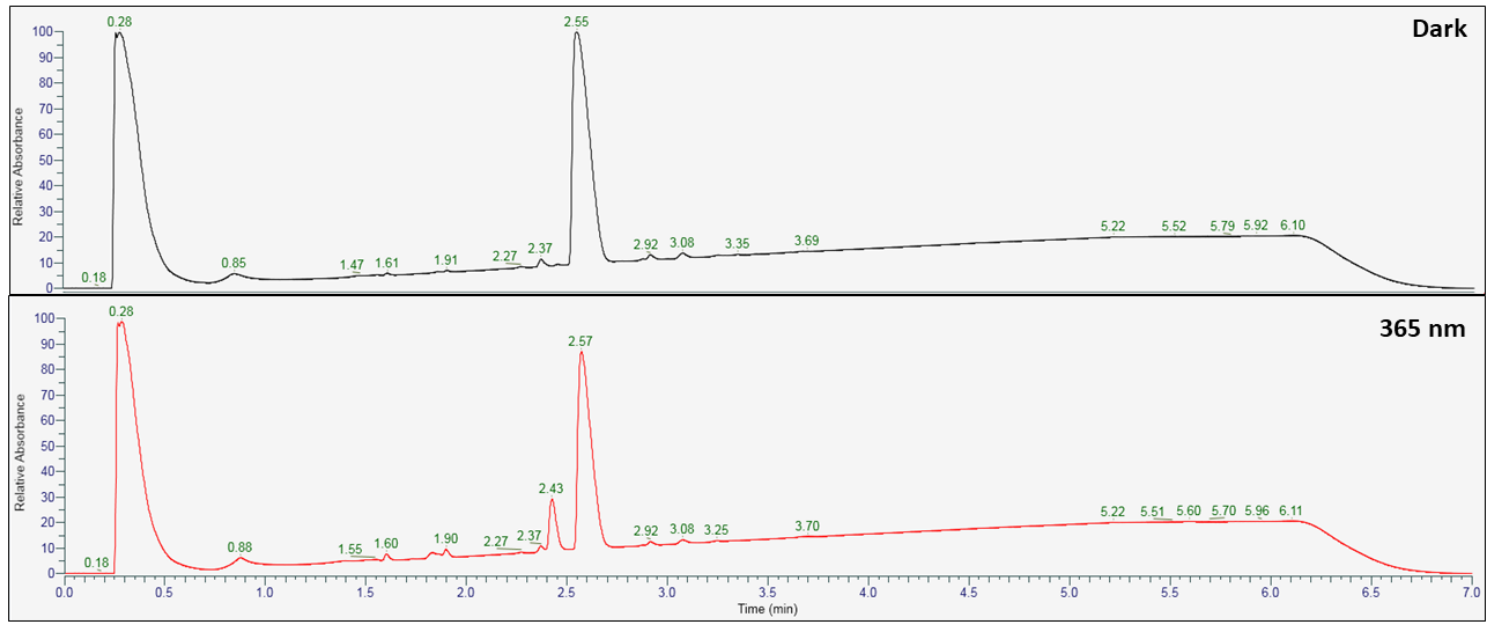

Figure S4. Photoisomerization of 9a. UPLC chromatogram of the dark-adapted state (black line, $2.55 \mathrm{~min}$ [100\%]) and $365 \mathrm{~nm}$ irradiated (red line, $2.43 \mathrm{~min}$ [12\%] and 2.57 $\min [88 \%])$.

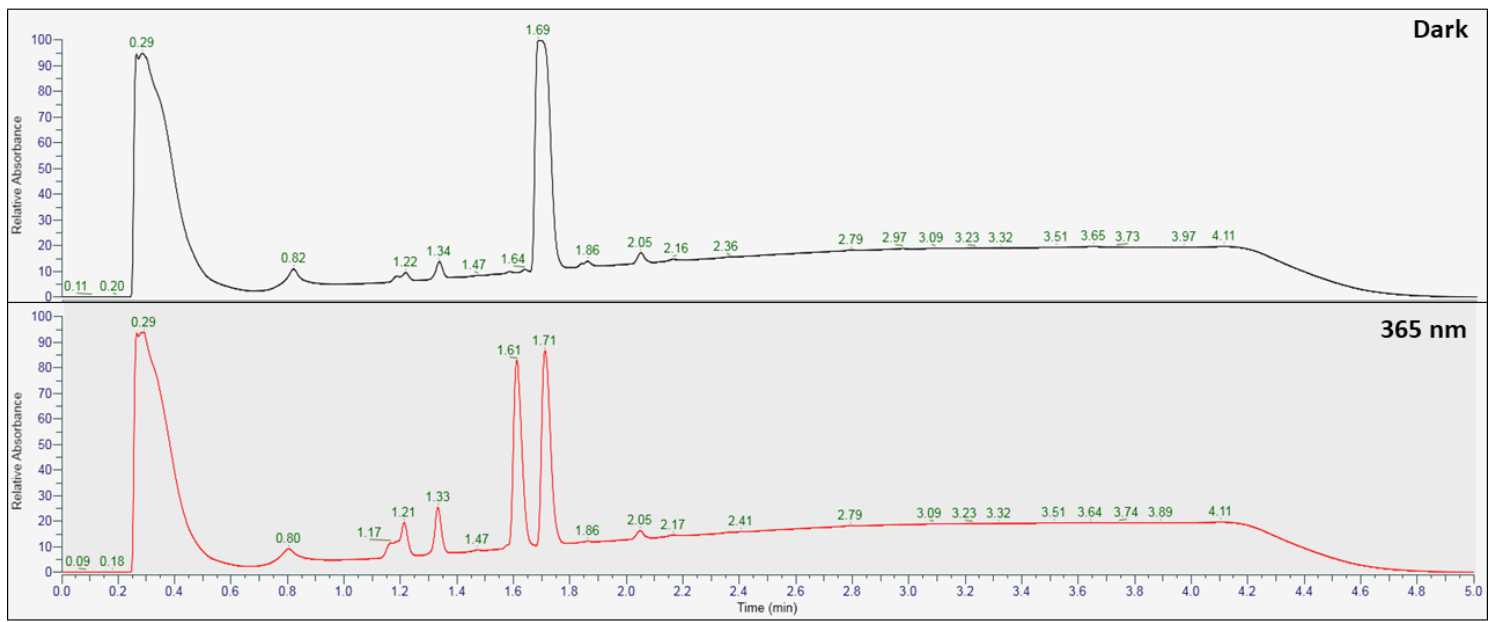

Figure S5. Photoisomerization of 9d. UPLC chromatogram of the dark-adapted state (black line, $1.69 \mathrm{~min}$ [100\%]) and $365 \mathrm{~nm}$ irradiated (red line, $1.61 \mathrm{~min}$ [50\%] and 1.71 $\min [50 \%])$. 


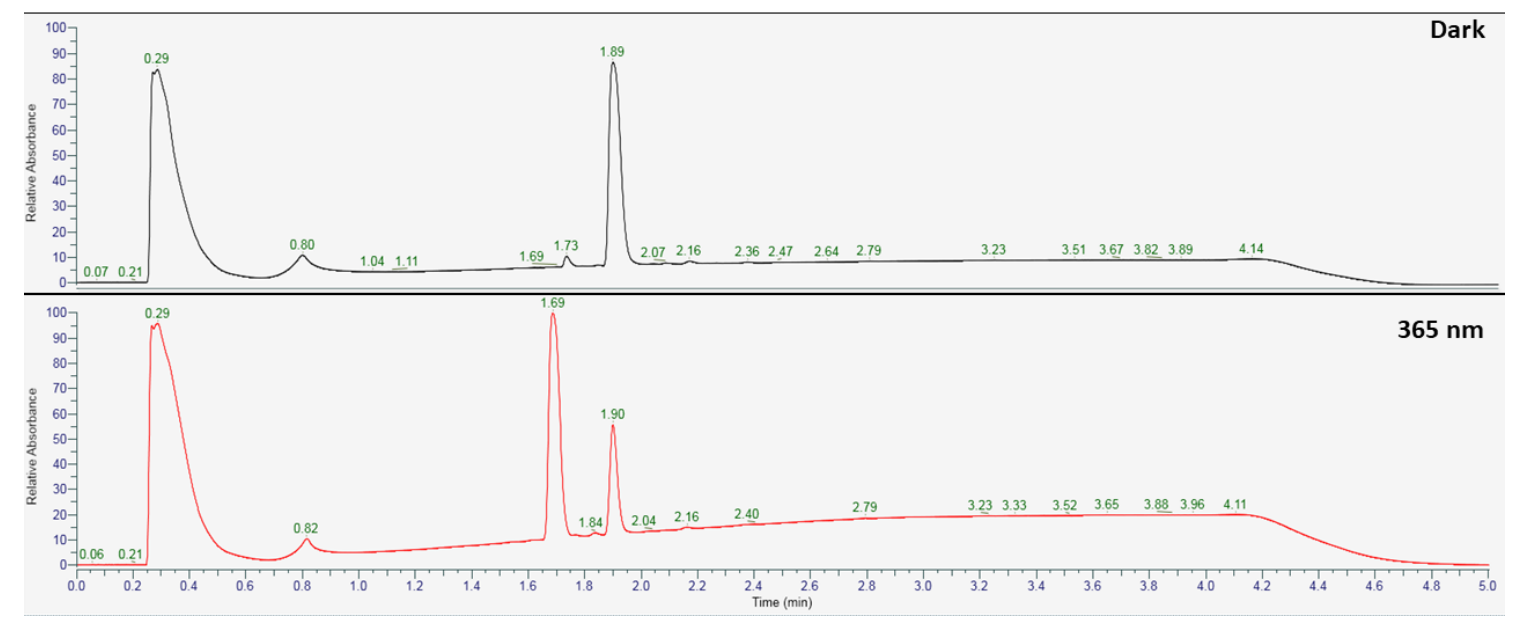

Figure S6. Photoisomerization of 9e. UPLC chromatogram of the dark-adapted state (black line, 1.69 [3\%] and $1.89 \mathrm{~min}$ [97\%]) and $365 \mathrm{~nm}$ irradiated (red line, $1.69 \mathrm{~min}$ [75\%] and $1.90 \mathrm{~min}[25 \%])$.

\section{Analytical RP-UPLC purity for compounds 9a-e}

Table S1. Analytical RP-UHPLC purity of the final compounds

\begin{tabular}{cc}
\hline Compound & $\begin{array}{c}\text { UHPLC purity } \\
(\%)^{\mathbf{a}}\end{array}$ \\
\hline $\mathbf{9 a}$ & $>96$ \\
$\mathbf{9 b}$ & $>98$ \\
$\mathbf{9 c}$ & $>98$ \\
$\mathbf{9 d}$ & $>93$ \\
$\mathbf{9 e}$ & $>95$ \\
\hline
\end{tabular}

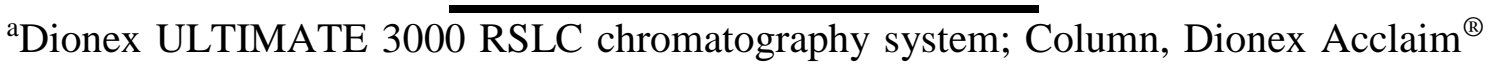
RSLC $120 \mathrm{C} 18,3.0$ × $50 \mathrm{~mm}$, particle size $2.2 \mu \mathrm{m}, 120 \AA$ pore size; UV Detection, ULTIMATE 3000 RS Photo diode array detector. Eluents, A: water with $0.05 \%$ TFA and D: Acetonitrile/water (9/1) with $0.05 \%$ TFA. The corresponding UHPLC gradients are given in the characterization of every compound.

\section{Biological methodology}

\subsection{Cell culture and FLIPR assay}

Calcium-5 was bought from Molecular Devices LLC. All other chemicals were purchased from Sigma-Aldrich. TRPV6 activity was measured using HEK293 cell line stably overexpressing human TRPV6 as previously reported. ${ }^{3-5}$ Stable cells were trypsinized and plated at 75,000 cells/well density onto poly-D-lysine coated 96-well black plates with clear bottom using $100 \mu$ l phenol-red free DMEM supplemented with 
$10 \%$ FBS and $2 \mathrm{mM}$ glutamine without antibiotics. $16 \mathrm{~h}$ later the medium was replaced with $90 \mu \mathrm{L}$ of nominally calcium-free (NCF) loading buffer (modified Krebs buffer containing $117 \mathrm{mM} \mathrm{NaCl}, 4.8 \mathrm{mM} \mathrm{KCl}, 1 \mathrm{mM} \mathrm{MgCl}$ 2, 5mM D-glucose, $10 \mathrm{mM}$ HEPES, and calcium- 5 fluorescence dye ( 0.5 vials per $10 \mathrm{ml}$ loading buffer $)$ ). Cells were incubated in the NCF-loading buffer at $37^{\circ} \mathrm{C}$ for $1 \mathrm{~h}$. Fluorescence $\mathrm{Cd}^{2+}$ measurements were carried out using FLIPRTETRA high throughput, fluorescence microplate reader. Cells were excited using a 470-495 nm LED module, and the emitted fluorescence signal was filtered with a 515-575 nm emission filter (manufacturer's guidelines). Stable calciumfree baselines were established for 60 seconds before $10 \mu \mathrm{L}$ of a $10 \mathrm{X}$ compound was added to the cells. Cells were incubated at $37{ }^{\circ} \mathrm{C}$ and fluorescence was monitored in the presence of compound for an additional 5 minutes before administration of $100 \mu \mathrm{L}$ of a $2 \mathrm{X}$ substrate (final concentration of $50 \mu \mathrm{M}$ of $\mathrm{CdCl}_{2}$ ). The activity of TPRV6 was measured by calculating the area under the curve of the $\mathrm{Cd}^{2+}$ entry traces i.e. following administration of the substrate. Experiments were done with 6 repeats per group. Fluorescence signals were analyzed using the ScreenWorks 3.1.1.8 software (Molecular Devices). Relative $\mathrm{IC}_{50}$ values were determined using GraphPad ${ }^{\circledR}$ Prism (GraphPad® Software, v. 5.0, San Diego, CA, US). Inhibition curves were obtained by non-linear regression using the built-in $\log$ (inhibitor) vs. normalized response function.

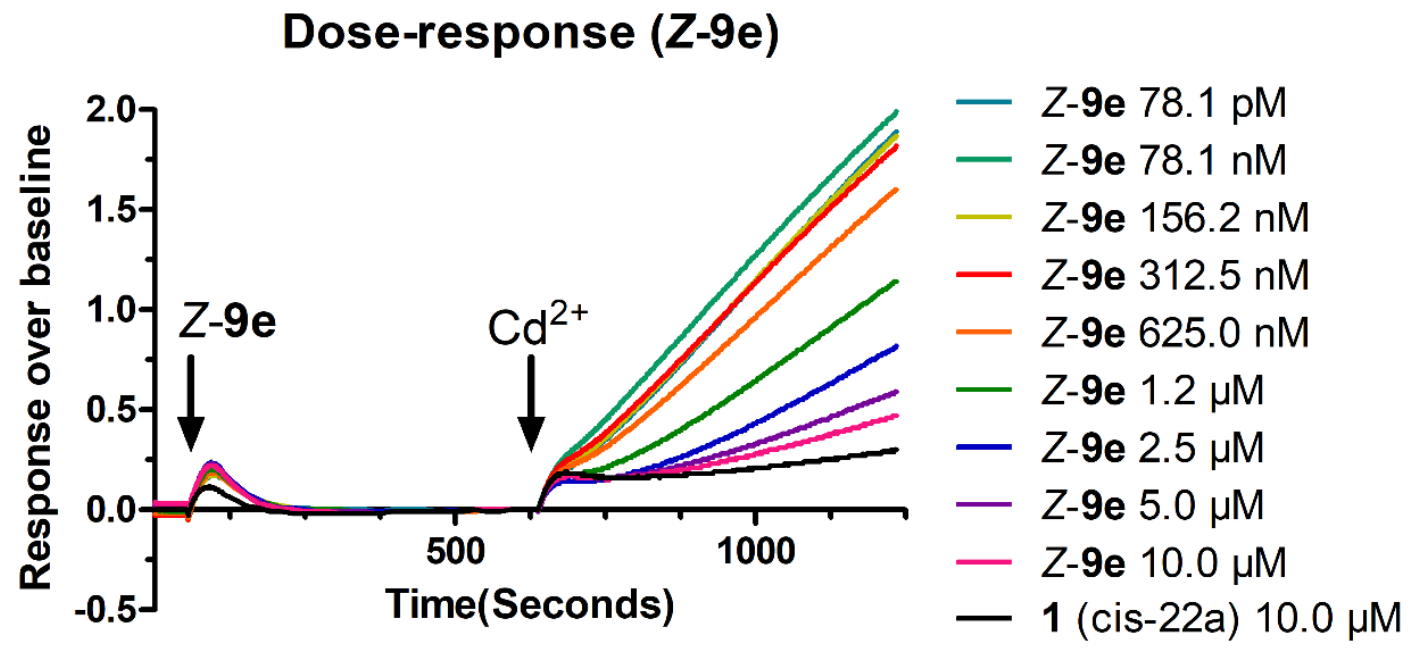

Figure S7. Dose-response curve $\left(\mathrm{Cd}^{2+}\right.$ traces $)$ of Z-9e. Each line represents a concentration of Z-9e ( $\mathrm{n}=6 /$ concentration). Cis-22a $=$ positive internal control. 


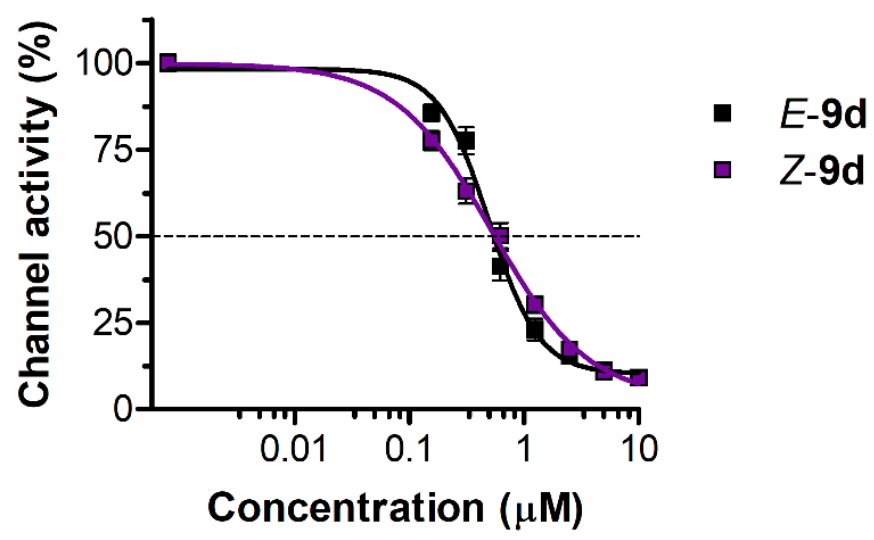

Figure S8. Inhibition curve of $\mathrm{Cd}^{2+}$ influx into HEK293- $h$ TRPV6 cells by $E / Z-9 d$ (black and magenta squares, respectively). Data shown are mean \pm SEM $(n=6 /$ concentration $)$ from 3 independent experiments.

\subsection{Electrophysiology.}

HEK293 cells (Leibnitz Institute DSMZ) were cultivated in DMEM medium containing $10 \% \mathrm{FCS}, 100 \mathrm{U} / \mathrm{ml}$ penicillin and $100 \mu \mathrm{g} / \mathrm{ml}$ streptomycin. $24 \mathrm{~h}$ prior the experiments, the cells were transiently transfected with the peYFP-C1 TRPV6 plasmid by using TransFectin ${ }^{\mathrm{TM}}$ Lipid Reagent (Bio-Rad). Patch-clamp experiments were conducted in the whole-cell configuration at room temperature $\left(20-24^{\circ} \mathrm{C}\right)$ with an $\mathrm{Ag} / \mathrm{AgCl}$ reference electrode. Voltage ramps from -90 to $+90 \mathrm{mV}$ over a time period of $200 \mathrm{~ms}$ were applied every $5 \mathrm{~s}$ from a holding potential of $50 \mathrm{mV}$. The light-activation and -deactivation of 9e by excitation at $365 \mathrm{~nm}$ and $470 \mathrm{~nm}$ was induced via a Polychrome IV monochromator (150 W Xe Lamp, Photonics). The internal pipette solution contained: $145 \mathrm{mM}$ Cs-methanesulfonate, $8 \mathrm{mM} \mathrm{NaCl}, 5 \mathrm{mM} \mathrm{MgCl} 2,10 \mathrm{mM}$ HEPES and $20 \mathrm{mM}$ EGTA, pH 7.2. The extra cellular solution $\left(10 \mathrm{mM} \mathrm{Ca}^{2+}\right)$ consisted of: $145 \mathrm{mM} \mathrm{NaCl}, 5$ $\mathrm{mM} \mathrm{CsCl}, 1 \mathrm{mM} \mathrm{MgCl}$, $10 \mathrm{mM}$ HEPES, $10 \mathrm{mM}$ glucose and $10 \mathrm{mM} \mathrm{CaCl}_{2}, \mathrm{pH}$ 7.4. The currents were leak-corrected by subtraction of the remaining leak currents after $\mathrm{La}^{3+}(10$ $\mu \mathrm{M})$ bock. The liquid junction potential was determined as $12 \mathrm{mV}$, though the voltages were not adjusted. All experiments were conducted at minimum 2 different days. The application of the corresponding amount (as of the inhibitor) of DMSO in $10 \mathrm{mM} \mathrm{Ca}^{2+}$ solution was used as a control. All statistical analyses and graphs were executed with OriginPro software (version 9.1, for Windows, OriginLab, Northampton, MA). To evaluate the effect of the inhibitor, the Wilcoxon signed rank test (2-sided) was conducted. 


\section{References}

(1) Lutz, T.; Wein, T.; Höfner, G.; Pabel, J.; Eder, M.; Dine, J.; Wanner, K. T.

Development of New Photoswitchable Azobenzene Based $\gamma$-Aminobutyric Acid (GABA) Uptake Inhibitors with Distinctly Enhanced Potency upon

Photoactivation. J. Med. Chem. 2018, 61 (14), 6211-6235.

(2) Schehr, M.; Ianes, C.; Weisner, J.; Heintze, L.; Müller, M. P.; Pichlo, C.; Charl, J.; Brunstein, E.; Ewert, J.; Lehr, M.; Baumann, U.; Rauh, D.; Knippschild, U.; Peifer, C.; Herges, R. 2-Azo-, 2-Diazocine-Thiazols and 2-Azo-Imidazoles as Photoswitchable Kinase Inhibitors: Limitations and Pitfalls of the Photoswitchable Inhibitor Approach. Photochem. Photobiol. Sci. 2019, 18 (6), 1398-1407.

(3) Simonin, C.; Awale, M.; Brand, M.; Van Deursen, R.; Schwartz, J.; Fine, M.; Kovacs, G.; Häfliger, P.; Gyimesi, G.; Sithampari, A.; Charles, R. P.; Hediger, M. A.; Reymond, J. L. Optimization of TRPV6 Calcium Channel Inhibitors Using a 3D Ligand-Based Virtual Screening Method. Angew. Chemie - Int. Ed. 2015, 54 (49), 14748-14752.

(4) Hofer, A.; Kovacs, G.; Zappatini, A.; Leuenberger, M.; Hediger, M. A.; Lochner, M. Design, Synthesis and Pharmacological Characterization of Analogs of 2Aminoethyl Diphenylborinate (2-APB), a Known Store-Operated Calcium Channel Blocker, for Inhibition of TRPV6-Mediated Calcium Transport. Bioorg. Med. Chem. 2013, 21 (11), 3202-3213.

(5) Kovacs, G.; Montalbetti, N.; Simonin, A.; Danko, T.; Balazs, B.; Zsembery, A.; Hediger, M. A. Inhibition of the Human Epithelial Calcium Channel TRPV6 by 2-Aminoethoxydiphenyl Borate (2-APB). Cell Calcium 2012, 52 (6), 468-480. 